\title{
Trace metals in the Ne Atlantic coastal zone of Finisterre (IBerian Peninsula): TERRESTRIAL AND MARINE SOURCES AND RATES OF SEDIMENTATION
}

\author{
Ricardo Prego*1, Juan Santos-Echeandía ${ }^{1,2}$, Patricia Bernárdez ${ }^{1}$, Antonio Cobelo-García ${ }^{1}$ \& \\ Manuel Varela ${ }^{3}$ \\ ${ }^{1}$ Marine Research Institute (IIM-CSIC), Av. Eduardo Cabello, 6. E-36208 Vigo, Spain \\ ${ }^{2}$ Centro Oceanográfico de A Coruña (IEO), Muelle de las Animas s/n. E-15001 A Coruña, Spain. \\ * Corresponding author: prego@iim.csic.es; Fax: +34986292762
}

\begin{abstract}
The biogeochemical patterns of bioactive metals ( $\mathrm{Cd}, \mathrm{Co}, \mathrm{Cu}, \mathrm{Ni}, \mathrm{V}$ and $\mathrm{Zn}$ ) and $\mathrm{Pb}$ were studied in the Corcubión Sound, an area close to Cape Finisterre (NW Iberian Peninsula). Seasonal patterns of dissolved and particulate trace metals in the freshwater and seawater, as well as in the phytoplankton were determined during three upwelling events in the winter, late spring and summer of 2005. Metals were also analysed in the surface and to $1 \mathrm{~m}$-depth in the sediments. Upwelling patterns permit the discrimination between those of the outer Sound and Corcubión Inlet. Dissolved trace metals concentrations in the seawater of the outer Sound were in the range of those reported for the Northeast Atlantic Ocean. Mean values of dissolved metals concentrations in the upwelled ENACW were: $0.07 \pm 0.03 \mathrm{nMCd}, 0.11 \pm 0.02 \mathrm{nMCo}, 2.6 \pm 1.6 \mathrm{nMCu}$, 4.6 $\pm 0.6 \mathrm{nMNi}, 0.20 \pm 0.10 \mathrm{nMPb}, 31 \pm 2 \mathrm{nMV}$ and $3.8 \pm 2.3 \mathrm{nMZn}$. Higher values for dissolved $\mathrm{Co}, \mathrm{Cu}$ and $\mathrm{Zn}$ were measured in two inflowing streams and in the Inlet. A severe-moderate contamination of these metals and $\mathrm{Pb}$ was detected in the sediments of the Inlet. Three different sediment layers were observed in cores located at the outer-Inlet boundary. The most recent showed the highest mass accumulation rates, mainly of $\mathrm{Cu}\left(\right.$ e.g. $\left.428 \mathrm{mgCu} \cdot \mathrm{m}^{-2} \cdot \mathrm{yr}^{-1}\right), \mathrm{Pb}$ and $\mathrm{Zn}$, during the last decade. The intermediate unit corresponds to the $20^{\text {th }}$ century (e.g. $39 \mathrm{mgCu} \cdot \mathrm{m}^{-}$ $\left.{ }^{2} \cdot \mathrm{yr}^{-1}\right)$ and the deeper layer from the $19^{\text {th }}$ to $14^{\text {th }}$ centuries can be regarded as representing the pre-industrial period, and show the lowest rates of metal accumulation (e.g. $7 \mathrm{mgCu} \cdot \mathrm{m}^{-2} \cdot \mathrm{yr}^{-1}$ ). Diatoms were the main autochthonous source of metals in the sediments. The genus Chaetoceros, Lauderia dominates in the overlaying seawater during winter and Pseudonitzschia and Leptocylindrus were typical of summer blooms whilst in the sediments Chaetoceros, Paralia, Leptocylindrus and Thalassionema were the main diatoms genera. The comparison of the normalized metal vs. Si in the phytoplankton and vs $\mathrm{Si}$ in the biogenic opal of the sediment shows a prevailing lithogenic-anthropogenic origin of metals such as $\mathrm{Cu}, \mathrm{Fe}, \mathrm{Ni}, \mathrm{Pb}$ and $\mathrm{V}$ while the upwelling was the main source for $\mathrm{Cd}$ in the sediments because of settling of diatoms. The continental influence and metal contamination is restricted to the innermost part of Sound during the last century where the anthropogenic activities supply $\mathrm{Cd}, \mathrm{Cu}, \mathrm{Pb}$ and $\mathrm{Zn}$. Seasonally, dissolved trace metals concentrations in the outer Sound are within the normal range measured in the north-eastern Atlantic Ocean. The Sound system is pristine compared with the neighbouring and anthropogenically disturbed Rias, and may be a good reference of natural trace metal levels along the north-eastern Atlantic coast.
\end{abstract}

Keywords: trace elements, heavy metals, sediment, water, SPM, phytoplankton, contamination, coastal waters, upwelling, Spain. 


\section{INTRODUCTION}

Coastal zones are areas of intense biogeochemical activity and their dynamic processes result in very productive ecosystems of great importance as much for nature conservation and study (Summerhayes et al., 1995) as for human management (Kay and Alder, 2005). The fluxes and processes occurring in the transition between land and ocean have been intensively researched in connection with the carbon, nitrogen and phosphorus cycles. International programs such as LOICZ have developed important studies of the natural and anthropogenically disturbed processes of nutrients at the coastal boundary, and particularly in estuaries (Smith et al., 2005). Despite this rapidly increasing knowledge of coastal ecosystems (Bianchi, 2007), the GEOTRACES Planning Group (2006) has stressed the need for the understanding of the biogeochemical cycling of trace elements. These serve as essential micronutrients or play an essential role in cell physiology and biochemical reactions besides the cycles of many trace elements (Morel et al., 2003; Hassler et al., 2004), which have been significantly affected by human activity (Laslett, 1995; Prego and CobeloGarcía, 2003 and the references cited therein).

Coastal ria regions, such as Galician in South-western Europe, are suitable marine areas to improve the knowledge of trace metal cycles. In the Galician region, the sources and sinks of material exchange between the land and the ocean do not only occur through the continental runoff interface as defined by Bruland and Lohan (2003) but also during upwelling events (Fraga, 1981). Trace metals bound on terrestrial material and resuspended river bed sediments which are transported to the coastal area by fluvial run-off are deposited in the surface sediment together with trace metals which originate from sinking phytoplankton (Varela et al., 2004).

Studies on the factors controlling the distribution of trace elements in the lberian continental shelf, and in particular the Galician coast, are still limited (Prego and Cobelo-García, 2003). This review of the metal research in rias and their interfaces before 2001 clearly show that studies dedicated to metals in the water column are lacking and need more attention. During the last decade the research conducted in the transition zones of rias were focussed on riverine trace metal inputs (Cobelo-García and Prego, 2004; Filgueiras and Prego, 2007; Santos-Echeandía et al., 2008), pelagic/benthic exchanges of metals (Santos-Echeandía et al., 2009a), and fluxes through the ria-ocean boundary (Cobelo-García et al., 2005a; Prego et al., 2006). Current information from the rias indicates that the trace metal cycles are influenced by human activities (Prego and Cobelo-García, 2003).

In the coastal zones bioactive metals play crucial roles as essential micronutrients of phytoplankton. Cadmium and $\mathrm{Zn}$ are fundamental in silica uptake by large diatoms, $\mathrm{Cd}, \mathrm{Co}, \mathrm{Zn}$ in $\mathrm{CO}_{2}$ acquisition or $\mathrm{Cu}, \mathrm{Ni}$ in organic nitrogen utilization (Morel and Price, 2003; Morel et al., 2003). Lead is not an essential micronutrient and its importance is because of its toxicity. The decrease of vanadium in coastal relative to oceanic waters has been assumed to be due to trapping by biotic material (Prange and Kremling, 1985; Yeats, 1992); Auger et al. (1999) have also connected it with the increase in particulate $V$ by the presence of a phase rich in iron oxyhydroxide and manganese oxides (Wehrli and Stumm, 1989).

The relevance of these bioactive metals and lead is suitable to acquire an overall view of their patterns in the Corcubión Sound. Thus, due to the low industrial activity and population of surrounding the Sound, together with uncontaminated conditions as regards metals observed in the Galician shelf sediments off the Western Rias (Santos-Echeandía et al., 2009b), it is hypothesized that the trace metal trend in the Corcubión Sound may represent pristine conditions. Consequently, the seasonal distribution of dissolved and particulate trace metals was studied in freshwater (dry and wet season) and seawater (three upwelling events), phytoplankton and sediments in the Sound environment, with the objectives of: (i) to obtain a dataset of trace 
metal concentrations in this area to provide a baseline for future researches; (ii) to investigate the importance of the land and sea sources of trace metals together with natural and anthropogenic influences to the coastal zone, and (iii) to evaluate the importance of sediment as a sink for metals in the Sound.

\section{THE STUDY AREA}

The Corcubión Sound is located between Cape Finisterre and the Western Rias (Fig.1). The surface temperature minimum during the coastal upwelling events in the Galician coast occurs around Cape Finisterre (Prego and Bao, 1997). The deep channel and the gulf-like shape, the scarce freshwater contribution and the low population density of this coastal region are the main Sound differences in comparison to the Western Rias (Evans and Prego, 2003). The Sound seems to be a suitable place to obtain a complete view of trace metal distribution and uptake and patterns of sedimentation of the ria type coastlines.

The Corcubión Sound (Fig.1) is an $8 \mathrm{~km}$ arm of the sea with a 50-90 $\mathrm{m}$ deep channel and a shallower inner zone ( $<30 \mathrm{~m}$ depth) formed by the Ezaro and Corcubión Inlets. On the dammed Xallas River in Ezaro are six power stations. The Cee stream in Corcubión flows with a current velocity of $<2 \mathrm{~m}^{3} \cdot \mathrm{s}^{-1}$. The Sound has an area of $112 \mathrm{~km}^{2}$ and is bordered on the southern littoral by the Finisterre Cape, the Carnota Beach and the Pindo Mountains (600 $\mathrm{m}$ above sea level). The entire area is a rugged coast with frequent reefs and the rocky islands of Lobeiras occur in the middle sound.

The climate is humid-temperate ( $\mathrm{Cfb}$ Köppen type) with an annual average temperature of $13.1^{\circ} \mathrm{C}$ and $1370 \mathrm{~mm}$ of rainfall. South-westerly winter storms coming from of Atlantic Ocean are common in winter whereas northerly winds predominate during summer. Therefore, the study area is influenced by upwelling events which develop close to Cape Finisterre.

The land areas surrounding the landmass are composed of igneous rocks, with a predominance of two-mica granites. The coast supports a dispersed population (136 inhab $\mathrm{km}^{-2}$ ) which is engaged in activities related to the primary sector: mainly agriculture and wood extraction, fishing and shellfishing. The main local industry is the factory of Metallic Carbides in Cee town. There are two sewage treatment plants (STP) in the Sound area, one in Finisterre town $(3,000$ inhabitants $)$ and the other which receives the wastewater of the towns of Corcubión and Cee (5,000 inhabitants).

\section{MATERIAL AND METHODS}

\subsection{Water and sediment sampling}

Three water sampling cruises were carried out in winter (February, 19th) spring (May, 6th) and summer (July, 6th) during the year 2005 on board of R/V Lura, a wooden ship. Vertical profiles of salinity and temperature were measured at 14 stations (numbered from 1 to 14 in Fig.1) using a CTD Sea-Bird 25. Upwelling indices (UI) were calculated by means of the geostrophic wind speed obtained from atmospheric pressure fields (supplied by the Spanish Metheorological Agency: AEMET) at grid reference $43^{\circ} \mathrm{N}, 11^{\circ} \mathrm{W}$ using the method described by Bakun (1973). During each cruise, seawater samples were taken using Go-Flo $5 \mathrm{~L}$ bottles (General Oceanic) in the water column at depth levels of $1,10,40,80 \mathrm{~m}$, depth permitting, at three stations A, B and C (Fig.1). In addition, surface water samples were taken using a telescopic arm at the mouths of the Xallas River and Cee stream, as well as at the site of the dump of the Cee sewage treatment plant (STP). Salinity and temperature were measured using a WTW MultiLine F/Set-3 and freshwater 
conditions verified. Samples were stored in 1-L LDPE (low-density polyethylene) bottles previously acid-washed and rinsed with Milli-Q water $\left(\mathrm{pH} 2\right.$ with $\left.\mathrm{HNO}_{3}\right)$, kept at $4^{\circ} \mathrm{C}$ in a refrigerator and transported to the land laboratory for the pre-treatment. Trace metals ultra-clean techniques were used during all the sampling procedure to avoid any contamination (Howard and Statham, 1993). Water samples for determination of chlorophyll were taken at stations A and C (Fig.1) at 0 , 5 and $10 \mathrm{~m}$ depth (photic zone) in darkened polycarbonate bottles of $250 \mathrm{~mL}$. Phytoplankton samples for cell counting were stored in $100 \mathrm{~mL}$ plastic bottles. In addition, phytoplankton samples were collected by net at each station during the morning (before 12:00 GMT) and evening (around 17:00 GMT). Two oblique tows from the bottom to the surface of a Juday-type net Bogorov of 40 microns mesh size were used. Samples were placed in plastic bottles and kept at $4{ }^{\circ} \mathrm{C}$ in the refrigerator.

Two sediment cruises have been carried out. The first cruise was aboard R/V Lura in the Corcubión Sound at May, 5th (2005). Fifteen samples of surface sediment were collected using a Shipeck grab, i.e. the stations numbered from 1 to 15 in Fig.1. The top sediment layer $(1-\mathrm{cm}$ thickness) was collected with a plastic spatula, placed into LDPE containers and kept in a refrigerator at $4^{\circ} \mathrm{C}$. The second cruise was aboard R/V Mytilus in the Corcubión Inlet mouth at December, 13th (2007). A sediment core (95 cm length) was collected in a PVC tube using a Gravity-Corer (42 $2^{\circ} 56.094^{\prime} \mathrm{N}$; $9^{\circ} 10.803^{\prime} \mathrm{W}$; St.+ in Fig.1; surface sediment was sampled with a Shipeck grab). The sediment core was sectioned longitudinally into two halves, and 16 subsamples of $1 \mathrm{~cm}$ thickness were taken from each $5 \mathrm{~cm}$ interval from the level of 4-5 to $79-80 \mathrm{~cm}$. The sediment samples were stored in plastic containers and kept at $4^{\circ} \mathrm{C}$ in a refrigerator until analysed. Additionally, 12 sediment samples were collected from sediment depths 1 to $27 \mathrm{~cm}$ for ${ }^{210} \mathrm{~Pb}$ dating.

\subsection{Water processing and analysis}

In the onshore laboratory (IIM-CSIC), water samples for dissolved trace metals were filtered through $0.45 \mu \mathrm{m}$ filters fitted in the plastic filter holders (Nalgene) inside a laminar flow cabin (ISO 5 class) located in a clean lab (ISO 6-7 class). Filtrates were transferred to acid-cleaned LDPE bottles, acidified to $\mathrm{pH} 2$ with nitric acid (Merck Suprapur ${ }^{\oplus}$ ) and packed in zip-lock plastic bags until analysis.

Dissolved trace metals were determined by stripping voltammetry after UV-digestion for $1 \mathrm{~h}$ using UV-Digestor apparatus (Achterberg and van den Berg, 1994). Cadmium, $\mathrm{Pb}$ and $\mathrm{Zn}$ analysis were carried out using the method of standard additions by means of differential pulse anodic stripping voltammetry (DPASV) in a Metrohm VA-694 equipped with a hanging mercury drop electrode (HMDE) as the working electrode. Cobalt, $\mathrm{Cu}, \mathrm{Ni}$ and $\mathrm{V}$ were determined by adsorptive cathodic stripping voltammetry (AdCSV) using the same equipment as described before for the DPASV method (Cobelo-García et al., 2005b). A blank test was run every five samples and results were blank-corrected. The detection limit, calculated as three times the standard deviation of the blank analysis ( $3 \sigma$ criterion), was found to be $20 \mathrm{pM}$ for $\mathrm{Cd}$ and $\mathrm{Pb}$ and $0.5 \mathrm{nM}$ for $\mathrm{Zn}, 0.10 \mathrm{nM}$ for $\mathrm{Co}$ and $0.4 \mathrm{nM}$ for $\mathrm{Cu}, \mathrm{Ni}$ and $\mathrm{V}$. The accuracy of the analytical procedure was assessed by the analysis of the CASS-4 certified reference material (near-shore seawater, National Research Council of Canada), and there was a good agreement with the certified concentrations (Table 1).

Samples for the determination of chlorophyll $a, b$ and $c$ were filtered through fibreglass filters (Whatman GF/F). Chlorophyll was extracted with 90\% acetone solution (UNESCO, 1994) and its concentration determined by spectrofluorimetry following the methods described by Neveux and Panouse (1987). Phytoplankton samples were preserved with Lugol's solution and kept in the dark until counting. Samples were counted as cells $\mathrm{mL}^{-1}$ using a Nikon Diaphot TMD inverted 
microscope. More than 500 cells per sample were counted and identified. Species nomenclature was validated according to Tomas (1997).

\subsection{Suspended particulate matter and sediment processing and analysis}

The suspended particulate matter (SPM) was collected after vacuum filtration, using Pall hydrophilic polypropylene membranes mounted in a polycarbonate filter holder, inside a laminar flow cabin (ISO 5 class) in a clean lab (ISO 6-7 class). The filtration was done through a $0.45 \mu \mathrm{m}$ filter circles and this was used to define the separation between dissolved and particulate components (Loring and Rantala, 1992; Neal et al., 1996). Pre-weighed and previously acid washed filters with pore size $0.45 \mu \mathrm{m}$ were used for filtration. The coated filters were dried in a laminar flow cabin (ISO 5 class), weighed and placed in cleaned air-tight plastic Petri dishes inside zip-lock plastic bags and stored at $-20^{\circ} \mathrm{C}$ in the freezer until digestion. Filter blanks were treated with the same procedure.

Surface and core sediment samples were dried slowly in an oven at $50^{\circ} \mathrm{C}$ and sieved through $2 \mathrm{~mm}$ sieves. The percentages of water content and mud+sand fraction were calculated. Later, samples were homogenized and stored in polyethylene containers at room temperature. Metal determinations were carried out on the fraction $<2 \mathrm{~mm}$. Prior to analysis, filters containing SPM and sediment samples were microwave-digested (Milestone 1200 Mega) in Teflon bombs using a mixture of $\mathrm{HNO}_{3}$ and $\mathrm{HF}$ according to EPA guideline 3052 (EPA, 1996).

According to the content level of metal in the samples, analyses were conducted using ETAAS (Varian 220) equipped with Zeeman background correction for the determination of $\mathrm{Cd}, \mathrm{Co}, \mathrm{Cu}$, $\mathrm{Fe}, \mathrm{Ni}, \mathrm{Pb}, \mathrm{V}$ and $\mathrm{Zn}$ in SPM, phytoplankton, surface sediment and core sediment. Sedimentary Al, $\mathrm{Fe}, \mathrm{Zn}$ and Si were measured with FAAS (Flame-Atomic Absorption Spectrophotometry, SpectrAA 220FS, Varian Inc.). The accuracy of the analytical procedure was checked using the reference materials PACS- 2 (marine sediment reference material, NRCC) and were in good agreement with the certified values (Table 1 ).

Biogenic opal was determined using the method of Mortlock and Froelich (1989). Approximately $200 \mathrm{mg}$ of dried sediment was treated with $5 \mathrm{~mL}$ of $\mathrm{HCl}(1 \mathrm{M})$ and $5 \mathrm{~mL}$ of $\mathrm{H}_{2} \mathrm{O}_{2}$ to remove carbonates and organic matter. Silica was measured photometrically according to the method of Hansen and Grasshoff (1983) using a continuous flow analyser AutoAnalyser Technicon II. Precision of the biogenic silica measurement is evaluated from replicate analyses of surface samples giving a coefficient of variability (e.g. standard deviation) of \pm 0.2 (Bernárdez et al., 2005).

The procedure for the treatment of raw material for bio-siliceous counts in the surface sediment of inner (Stations 1-3; Fig.1) and outer (St.11-14) Sound follows the technique developed by Abrantes et al. (2005a), as applied to rias by Bernárdez et al. (2008) following the recommendations of Schrader and Gersonde (1978). At least 100 species were counted and identified in each sample, which is sufficient for the interpretation of the proportional distribution of the dominant taxa (Fatela and Taborda, 2002). Several floras and well-known bibliographies were used for taxonomic identification and grouping (Hasle and Syvertsen, 1996; Witkowski et al., 2000), based on their ecological characteristics.

In order to estimate the upper sedimentation rate 12 subsamples were recovered in a vertical profile from the topmost $27 \mathrm{~cm}$ of the core; their ${ }^{210} \mathrm{~Pb}$ activity was determined by the direct measurements of its gamma decay energies at $46.5 \mathrm{keV}$. Geochronological analyses (Lesueur et al., 2001) in the Mixed Research Unit (UMR 5805) of Oceanic Environments and Palaeoenvironments (EPOC) shared between CNRS and Bordeaux 1 University. In addition, a marine bivalve shell, recovered in the sediment core at $66 \mathrm{~cm}$ depth bsf, was ${ }^{14} \mathrm{C}$ dated. Dating 
was performed (ref. Poz-24227) at the AMS facility of the Poznan Radiocarbon Laboratory (Poland).

\section{RESULTS}

\subsection{Natural metal distribution and contamination levels in sediments \\ 4.1.1. General sediment properties}

Core and surface sediment samples in the Sound were mainly muddy though partially mixed with fine sands in the outer part with occasional shells or small pebbles that were sieved. The $<2$ $\mathrm{mm}$ size fraction was always a major fraction of the sediment comprising $95 \pm 5 \%$ of the total. Approximately $50 \%$ of the initial wet sediment was water, i.e. an average of $54 \pm 5 \%$ in the core and $45 \pm 10 \%$ in the surface sediment. Lithogenic constituents, traced by aluminium, ranged between 21 and $56 \mathrm{gAl} \cdot \mathrm{kg}^{-1}$ in the core and $15-90 \mathrm{gAl} \cdot \mathrm{kg}^{-1}$ in the surface sediment.

The total silicon of these surface sediments (Fig.2) varied between 60 and $234 \mathrm{~g} \cdot \mathrm{kg}^{-1}$ with the exception of St.15, close to Metallic Carbides factory, with a content of $402 \mathrm{gSi} \cdot \mathrm{kg}^{-1}$. The biogenic silicon fraction (opal), composed mainly by diatoms, had mean values of $8.2 \pm 1.9 \mathrm{gSi} \cdot \mathrm{kg}^{-1}$. Opal versus lithogenic matter shows an average silicon ratio of 1:127 in the surface sediments of the main channel of the Sound (Fig.1).

\subsubsection{Sediment core dating}

${ }^{210} \mathrm{~Pb}$ dating method was applied for the uppermost part of the core (Fig.3). The sedimentation rates were established according to the constant flux:constant sedimentation model, giving a result of $0.88 \mathrm{~cm} \cdot \mathrm{yr}^{-1}$ for the upper seven centimetres $(2007-2000)$ and $0.20 \mathrm{~cm} \cdot \mathrm{yr}^{-}$ ${ }^{1}$ in the underlying twenty centimetres (1999-1893).

A marine bivalve shell located in the $66 \mathrm{~cm}$-depth core level was ${ }^{14} \mathrm{C}$ dated and gave an uncorrected radiocarbon age of $1035 \pm 30$ years. It was corrected for ${ }^{13} \mathrm{C}$ and for the marine reservoir age $(\delta R=376 \pm 46)$ with the Calib 5.0.1 software (Stuiver and Reimer, 1993 modified version 2002: http://calib.qub.ac.uk/calib/) using the Marine04 calibration dataset for radiocarbon ages younger than $26,000{ }^{14} \mathrm{C}$ years (Hughen et al., 2004). In upwelling-influenced areas, such as off Galicia, reservoir ages may be higher than the global reservoir correction value. However, as pointed out by Abrantes et al. (2005b), the local reservoir-effect correction is negligible and was not applied. Thus, the obtained calibrated age was reported as cal. yr BP (calibrated years Before Present), giving a result of $601 \pm 59 \mathrm{cal}$. yr BP at the $66 \mathrm{~cm}$-depth core level. This gave an average sedimentation rate of $0.08 \mathrm{~cm} \cdot \mathrm{yr}^{-1}$ for the lowermost part of the core.

The metal accumulation rates (MAR in $\mathrm{mg} \cdot \mathrm{m}^{-2} \cdot \mathrm{yr}^{-1}$ ) for each element were calculated using the following equation:

$$
\text { MAR }=10 \cdot[\mathrm{Me}] \cdot \mathrm{S}_{\mathrm{r}} \cdot \mathrm{DBD}
$$

where $[\mathrm{Me}]$ is the metal content of each studied element in $\mathrm{mg} \cdot \mathrm{kg}^{-1}, \mathrm{~S}_{\mathrm{r}}$ the obtained sedimentation rates for each core levels in $\mathrm{cm} \cdot \mathrm{yr}^{-1}$ and DBD a dry bulk density of the sediment of 2 $\mathrm{g} \cdot \mathrm{cm}^{-3}$.

\subsubsection{Historical trend of metals in the sediment core}

Metals can be divided into two groups according to their behaviour (Fig.4). The first group shows the highest contents in the uppermost sediment layers and a decrease down-core reaching almost constant levels at sediment depths $>20 \mathrm{~cm}$. The elements showing this trend were $\mathrm{Cd}$ with $0.2-0.3 \mathrm{mg} \cdot \mathrm{kg}^{-1}$ from 20 to $80 \mathrm{~cm}$-depth increasing its content up to $0.6 \mathrm{mg} \cdot \mathrm{kg}^{-1}$ at $5 \mathrm{~cm}$-depth; $\mathrm{Cu}$ with 5-9 mg. $\mathrm{kg}^{-1}$ and $27 \mathrm{mg} \cdot \mathrm{kg}^{-1}$ in the top core; $\mathrm{Pb}$ with 9-14 mg. $\mathrm{kg}^{-1}$ increasing up to $53 \mathrm{mg} \cdot \mathrm{kg}^{-1}$ 
and $\mathrm{Zn}$ with $50-70 \mathrm{mg} \cdot \mathrm{kg}^{-1}$ and $213 \mathrm{mg} \cdot \mathrm{kg}^{-1}$ in $5 \mathrm{~cm}$-depth. All of these show the same pattern of distribution when they were normalized to Al (Fig.4).

In the second group, the metals increased their contents slightly and gradually from the core bottom to the topmost sediment (St.3). Cobalt increased from 2 to $6 \mathrm{mg} \cdot \mathrm{kg}^{-1} ;$ Fe from 9 to $28 \mathrm{~g} \cdot \mathrm{kg}$

'; Ni from 13 to $26 \mathrm{mg} \cdot \mathrm{kg}^{-1}$ and $\mathrm{V}$ from 26 to $77 \mathrm{mg} \cdot \mathrm{kg}^{-1}$. However, when these were normalized with respect to $\mathrm{Al}$ the Metal/Al ratio did not show an increase but had fluctuating profiles over a short range (Fig.4). Normalization with $\mathrm{Al}$ for $\mathrm{Co}, \mathrm{Ni}$ and $\mathrm{V}$ showed an increase in their ratios at depths of 50-55 cm as was found also for Cd/Al.

The metal sedimentation rates are shown in the Table 2 . Three different rates were observed corresponding to recent (2000-2007), industrial (1983-1999) and pre-industrial (before 1893) periods. The sedimentation rates in the pre-industrial period, which were $0.4 \mathrm{mgCd} \cdot \mathrm{m}^{-2} \cdot \mathrm{yr}^{-1}$, $3 \mathrm{mgCo} \cdot \mathrm{m}^{-2} \cdot \mathrm{yr}^{-1}, 7-17 \mathrm{mg} \cdot \mathrm{m}^{-2} \cdot \mathrm{yr}^{-1}$ to $\mathrm{Cu}, \mathrm{Ni}$ and $\mathrm{Pb}, 50 \mathrm{mVg} \cdot \mathrm{m}^{-2} \cdot \mathrm{yr}^{-1}$ and 15 and $0.65 \mathrm{~g} \cdot \mathrm{m}^{-2} \cdot \mathrm{yr}^{-1}$ to $\mathrm{Fe}$ and $\mathrm{Zn}$, respectively, increased at the end of XIX century. Thus, these metals showed contents in the industrial age which were 4-5 fold higher than previously. These increases became 25-30 those measured for the XV-XIX centuries as regards to $\mathrm{Cd}, \mathrm{Co}$, Fe and $\mathrm{Ni}$; it was especially evident as regards to $\mathrm{Cu}$ ( 55 fold) and $\mathrm{Pb}$ ( 80 fold) whilst $\mathrm{Zn}$ showed only a 4 fold increase.

\subsubsection{Metal background}

The state of the degree of contamination in a coastal environment requires the selection of a reference metal in the sediments (Luoma et al., 1990). Aluminium is a suitable normaliser because it is a major constituent of the fine fraction and contamination does not change the content of this element (Loring, 1991; Hanson et al., 1993). Aluminium has already been used for this propose in temperate granitic zones (Salomons et al., 1985; Windom et al., 1989; Prego and Cobelo-García, 2003)

Therefore, with the aim of determining the background levels of metal (Me) contents in the core of Sound these were plotted versus $\mathrm{Al}$, in order to obtain a regression line:

$$
[\mathrm{Me}]_{\mathrm{B}}=\mathrm{a} \cdot[\mathrm{Al}]+\mathrm{b}
$$

where units are in $\mathrm{mg} \cdot \mathrm{kg}^{-1}$ except for Fe and $\mathrm{Al}$, in $\mathrm{g} \cdot \mathrm{kg}^{-1}$.

The data of the metal contents from the topmost sediment (from 5 to $20 \mathrm{~cm}$-depth, inclusive) were ignored in order to calculate the regression lines with only pre-industrial contents (see Fig.4). Standard equations ( $n=12)$ are:

$$
\begin{array}{ll}
{[\mathrm{Cd}]=0.26 \pm 0.04} & \\
{[\mathrm{Co}]=0.090 \cdot[\mathrm{Al}]+0.17} & (r=0.95) \\
{[\mathrm{Cu}]=0.167 \cdot[\mathrm{Al}]+0.83} & (r=0.93) \\
{[\mathrm{Fe}]=0.414 \cdot[\mathrm{Al}]-0.79} & (r=0.97) \\
{[\mathrm{Ni}]=0.367 \cdot[\mathrm{Al}]+3.14} & (r=0.92) \\
{[\mathrm{Pb}]=0.248 \cdot[\mathrm{Al}]+3.47} & (r=0.86) \\
{[\mathrm{V}]=1.022 \cdot[\mathrm{Al}]+11,2} & (r=0.92) \\
{[\mathrm{Zn}]=0.711 \cdot[\mathrm{Al}]+30.6} & (r=0.77)
\end{array}
$$

In this way the theoretical natural values can be established and make it possible to know the levels where metal enrichment is due to contamination. Metal content increases with aluminium content, equations (3) to (9), except for cadmium, equation (2), which exhibits a nonAl dependent behaviour.

The normalized enrichment factor (NEF) is defined as the number of times that the natural or reference content is exceeded (Tanner et al., 2000) and is calculated by the following formula:

$$
\mathrm{NEF}_{\mathrm{n}}=[\mathrm{Me}]_{\mathrm{n}} /\left[\mathrm{Me}_{\mathrm{BL}}\right]_{\mathrm{n}}
$$


where $\mathrm{n}$ is the sampling station and $\mathrm{BL}$ the background value obtained from Al-metal equations (2) to (9). Then, based on Hakanson (1980), the sediment contamination from NEF results can be classified as follows:

negligible $<1<$ possible $<2<$ moderate $<3<$ severe $<6<$ very severe

\subsubsection{Metal contamination of the sediment}

Metal contents in the surface sediment of the Sound decreased from the innermost stations of Corcubión Inlet as far as Station 12 (outer zone), followed by a small increase seaward in Stations 13 and 14 (Fig.2). The highest contents occur at Station 2, being particularly high for Zn, $\mathrm{Pb}, \mathrm{Ni}$ and $\mathrm{V}$. Total silicate content rises to 235 and $149 \mathrm{~g} \cdot \mathrm{kg}^{-1}$ in the two innermost stations and in the 169 and $184 \mathrm{~g} \cdot \mathrm{kg}^{-1}$ in the outermost stations. Nevertheless, the highest Si content was measured at Station $15\left(403 \mathrm{~g} \cdot \mathrm{kg}^{-1}\right)$, which was located inside the harbour of the metallic carbides factory, however the metal contents were similar to those of the sediments of the outer Sound.

From the background contents of metals in sediments, calculated from eq. (3) to (10), and the enrichment factor estimated from eq. (11), the contamination state can be defined in the Sound sediments. Following the aforementioned criteria, metal contamination is detected mainly in the Corcubión Inlet. There, a severe recent contamination occurs at Station 2 of $\mathrm{Cd}, \mathrm{Cu}$ and $\mathrm{Zn}$, while contamination is moderate for these metals in the remainder of this area. Throughout the Sound $\mathrm{Pb}$ is the most marked contaminant metal; it is specially severe in the Inlet whilst decreasing to moderate contamination in all the Sound, except that of Stations 10-13.

A moderate contamination of the sediments by the metals $\mathrm{Cu}, \mathrm{Pb}$ and $\mathrm{Zn}$, also occurred historically during the industrial period as the Metal/Al relationship suggests (Fig.4) and the NEF of 2-3 confirmed to the upper core part.

\subsection{Trace metals concentrations in the seawater column and continental contributions 4.2.1. Oceanographic conditions}

During the days previous to the three seasonal cruises in the Corcubión Sound the Cape Finisterre coast was under predominance of northerly winds. These winds moved the surface seawater layer offshore and in each case an upwelling event developed. The magnitude of offshore surface transport is suggested by the positive upwelling index (UI; Fig.5) that is equivalent to the Ekman transport derived from surface winds, and the number of days the wind blows. During the sampling on the 6 February upwelling was enhanced, lasting eight days and showed an UI of $640 \pm 360 \mathrm{~m}^{3} \cdot \mathrm{s}^{-1} \cdot \mathrm{km}^{-1}$. During the cruise in July upwelling was less pronounced with an UI of $390 \pm 310 \mathrm{~m}^{3} \cdot \mathrm{s}^{-1} \cdot \mathrm{km}^{-1}$. The weakest upwelling was recorded for the 16 May lasting just three days with a UI of $790 \pm 310 \mathrm{~m}^{3} \cdot \mathrm{s}^{-1} \cdot \mathrm{km}^{-1}$.

These northerly winds and their resulting westward currents, i.e. seaward along the western Galician coast, were expressed and were recorded inside the Corcubión Sound as a nonhomogeneous distribution of water density (see the $10 \mathrm{~m}$ depth isopycnal map; Fig.5). In February, the temperature of the water column in the Sound ranged between 11.4 and $12.2^{\circ} \mathrm{C}$ and a thermal inversion was observed. The salinity was higher than 35.0 below $3 \mathrm{~m}$ depth and in the upper water column there was a shallow layer which had a low salinity due to fluvial outputs. Salinity increased from the mouths of Xallas River (St.1 top, $S \approx 21$ ) and Cee stream (St.11, S $\approx 29$ ) to the mouth of the Sound. Due to the low temperature gradient both, density $\left(\gamma_{t} ;\right.$ Fig.5) and salinity isolines had a similar trend. In May, the temperature varied from 12.4 to $16.3^{\circ} \mathrm{C}$ and the salinity showed analogous vertical pattern to that found in February. However, the distribution of the isotherms was comparable to that of the isopycnals (Fig.5). A similar situation was found also in July. During July sampling the lowest temperature in the water column was $12.4^{\circ} \mathrm{C}$ with a surface 
west-east gradient of $16.3-14.1^{\circ} \mathrm{C}$ generated by the upwelled seawater. Salinities between 35.57 and 35.76 were recorded in July, except for a less salty surface layer of only $2 \mathrm{~m}$.

The three events displayed the same $\gamma_{t}$ pattern, with the maximum adjacent to the east shore of the Sound. These maxima varied following the aforementioned upwelling intensity, with values of $27.1,26.5$ and $27.0 \mathrm{~kg} \cdot \mathrm{m}^{-3}$, respectively. The upwelling in the Sound (Fig.5) clearly differentiates two main zones: (i) the east and outer zone mainly under the domain of upwelled seawater; (ii) and the partially isolated inner (Corcubión Inlet) and western (Finisterre Bay) zones.

According to the temperature-salinity diagram (Fig.6), the upwelled seawater inside the Corcubión Sound can be associated to the Eastern North Atlantic Central Water (ENACW). The water column reflects a greater influence in the outer than the inner Sound zone. In a FebruaryJuly-May sequence: seawater with the T-S characteristics of ENACW from the 1,6 and $40 \mathrm{~m}$ depth to the bottom occurs in the outer zone and in the inner Sound from $19 \mathrm{~m}$ (February) and $15 \mathrm{~m}$ (July) to the bottom, and is not present in May.

High concentrations of chlorophyll $(a+b+c)$ were measured In the Corcubión Sound superimposed on the upwelling influence. The highest chlorophyll concentration in the seawater was detected during the spring pre-bloom of February with values of 15.5 and $11.4 \mathrm{mg} \cdot \mathrm{m}^{-3}$ measured at $0 \mathrm{~m}$ depth in the Corcubión Inlet and outer Sound. Chlorophyll content was 1.3 $\mathrm{mg} \cdot \mathrm{m}^{-3}$ at $20 \mathrm{~m}$ (Inlet) and $5 \mathrm{~m}$ (outer) $\mathrm{mg} \cdot \mathrm{m}^{-3}$ in May, and in July values ranged between 1.8 and $5.3 \mathrm{mg} \cdot \mathrm{m}^{-3}$ both at $5 \mathrm{~m}$ depth in the Inlet and outer Sound. In summary, the higher chlorophyll concentrations were observed in the photic zone of Corcubión Inlet in the spring pre-bloom (14 $\left.\mathrm{mg} \cdot \mathrm{m}^{-3}\right)$ and in the outer zone of Sound in the summer upwelling $\left(4 \mathrm{mg} \cdot \mathrm{m}^{-3}\right)$.

\subsubsection{Dissolved trace metals in the waters of the Sound}

The trace metal concentrations in the water column of the Corcubión Sound were considered during each sampling with respect to the two main zones hydrographically observed in the Sound. Then, dissolved and particulate metals concentrations from each cruise were averaged for the inner part (Corcubión Inlet) from the levels measured at two stations (St.A and B; Fig.1) and for the outer zone were calculated (four sets of data) from St.C. Data on trace metal concentrations in the dissolved and particulate phases are shown as average \pm standard deviation (Tables 3 and 4).

Xallas River, the Cee stream and the STP of Cee supply freshwater to the Corcubión Sound. Dissolved metal concentrations of Xallas River and Corcubion Sound are of the same order of magnitude, i.e. $0.02-0.15 \mathrm{nM}$ of $\mathrm{Cd}, 0.1-0.3 \mathrm{nM}$ of $\mathrm{Co}, 1-14 \mathrm{nM}$ of $\mathrm{Cu}, 3-6 \mathrm{nM}$ of Ni, $0.5-0.1 \mathrm{nM}$ of $\mathrm{Pb}$ and 1-13 nM of $\mathrm{Zn}$ (Table 3). The exception is $\mathrm{V}$ that has ten-fold higher concentrations in the Sound (24-39 nM) than in the Xallas River. Trace metal levels in the Cee stream were similar to the Xallas River, except for $\mathrm{Cu}$ and $\mathrm{Pb}$ which showed 4 to 5 -fold higher values. On the contrary, sewage water from the Cee STP was rich in dissolved $\mathrm{Co}, \mathrm{Cu}, \mathrm{Pb}$ and $\mathrm{Zn}$. The other metals showed similar concentrations (Table 3).

The comparison of inner and outer Sound reveal that the seawater concentrations of dissolved $\mathrm{Co}, \mathrm{Cu}$ and $\mathrm{Zn}$ were higher in the Corcubión Inlet while $\mathrm{V}$ was lower. Cadmium, $\mathrm{Ni}$, and $\mathrm{Pb}$ did not differ significantly between both zones. Seasonally (Table 3), the concentrations of dissolved trace metals increased in the Inlet from winter (February) to summer (July) in the case of $\mathrm{Co}, \mathrm{Pb}$ and $\mathrm{Zn}$. In the Inlet the opposite, i.e. summer decreasing concentrations, occurred for $\mathrm{Cd}$ and $\mathrm{Cu}$. On the other hand, trace metals in the outer Sound showed the highest concentrations in spring (May) mainly: $\mathrm{Cd}, \mathrm{Co}, \mathrm{Pb}, \mathrm{V}$ and $\mathrm{Zn}$ while $\mathrm{Cu}$ was highest in winter and $\mathrm{Ni}$ in summer. However, the range throughout all the Sound was always lower than the $50 \%$ of average concentration, except for $\mathrm{Cu}$ and $\mathrm{Zn}$ that was twice that value. 


\subsubsection{Particulate trace metals in the water column of the Sound}

The rivers flowing into the Sound exhibit low suspended particulate matter (SPM) concentrations (Table 4). Fluvial contributions of the Xallas and the Cee ranged from 2 to $24 \mathrm{mg} \cdot \mathrm{L}^{-}$

${ }^{1}$ while the sewage of Cee STP was slightly higher $\left(7-52 \mathrm{mg} \cdot \mathrm{L}^{-1}\right)$. Comparatively, the water column of the Sound was poor in SPM $\left(<2 \mathrm{mg} \cdot \mathrm{L}^{-1}\right)$ being concentrated in the surface seawater $(0-5 \mathrm{~m}$ depth layer), where the chlorophyll maximum was found. The highest metal content in the SPM occurred in the Corcubión Inlet in February, where the average contents of metals (0-10 m depth) were $23 \pm 7 \mathrm{mgCu} \cdot \mathrm{kg}^{-1}, 7 \pm 2 \mathrm{gFe} \cdot \mathrm{kg}^{-1}, 12 \pm 7 \mathrm{mgNi} \cdot \mathrm{kg}^{-1}, 29 \pm 15 \mathrm{mgV} \cdot \mathrm{kg}^{-1}$ and $324 \pm 67 \mathrm{mgZn} \cdot \mathrm{kg}^{-1} ; \mathrm{Cd}$ was always less than $0.3 \mathrm{mg} \cdot \mathrm{kg}^{-1}$. SPM decreased $4-6$ fold lower in the outer Sound, except for Fe and $\mathrm{V}$, whose values dropped only down to $50 \%$ those of the inner part. On the other hand the particulate metals increased in the mouth of freshwater streams, where the content of $\mathrm{Cu}$ in SPM was 9-fold higher than SPM in the Inlet, $\mathrm{Fe}$ and $\mathrm{Pb}$ were 3 -fold higher, $\mathrm{Ni}$ 2-fold higher and $\mathrm{V}$ and Zn had similar contents.

Table 4 shows the particulate metal concentrations in $\mathrm{nM}$ (SPM $\left[\mathrm{mg} \mathrm{L}^{-1}\right] \times$ metal $\left[\mathrm{mg} \mathrm{kg}^{-1}\right]$ ). Generally, particulate metal concentrations were higher in the inner than in the outer Sound in all sampling cruises, except for $\mathrm{Pb}$ and $\mathrm{V}$. Cadmium and $\mathrm{Cu}$ especially emphasize the significance of particulate metals in the stream waters ( $\mathrm{Cd}: 2-11 \mathrm{nM}, \mathrm{Cu}$ : $\max 425 \mathrm{nM})$ when compared to the Sound waters $(\mathrm{Cd}<0.01 \mathrm{nM}, \mathrm{Cu}<0.5 \mathrm{nM})$.

In the water column of the Sound the relationship between the dissolved and the particulate metals (D/P), calculated as a dimensionless quotient between dissolved ( $n M)$ and particulate $(n M)$ concentrations, were always higher than 1 , i.e. dissolved metal concentrations were higher than the particulate. D/P ranged from 7 to 327 to $\mathrm{Cu}, 32-114$ to $\mathrm{Ni}, 3-11$ to $\mathrm{Pb}, 73-195$ to $\mathrm{V}$ and $1-28$ to $\mathrm{Zn}$. There are no data available for $\mathrm{D} / \mathrm{P}$ relationships of $\mathrm{Fe}$ and $\mathrm{Cd}$ as dissolved $\mathrm{Fe}$ was not measured and particulate $\mathrm{Cd}$ was below detection limit. Lowest ratios with a range of 1-6 for the investigated metals were observed in the inner Sound in February 2005, which may be caused by an increased river run-off in the winter months.

\subsubsection{Metal contents in marine phytoplankton}

Phytoplankton was collected from the water surface to the bottom in the Sound. Thus, the data presented here are related to the entire water column. Furthermore, trace metal contents which are presented in the following, are solely referred to the phytoplankton fraction $>20 \mu \mathrm{m}$ as sampling took place with a 40 mesh net. In any case this fraction is very abundant and was dominant in terms of biomass in the three cruises, mainly in February. These results (Table 5) can be considered as being representatives of the amount of trace metals bound on phytoplankton during upwelling periods.

The microphytoplankton of the Sound is dominated by a few genus of diatoms ( $>83 \%$ of abundance) in the water column associated to the three upwelling events, Chaetoceros (C. socialis mainly) and Lauderia (L. borealis mainly) as the predominant in February, Pseudonitzschia ( $P$. $c f$ pungens mainly) in May and Leptocylindrus (L. danicus mainly) and Pseudonitzschia (P. of delicatissima and $P$. cf pungens half-and-half mainly) in July (Table 5). Cell counts were higher in the Corcubion Inlet than in the outer Sound.

Chaetoceros, Paralia, Leptocylindrus and Thalassionema were the main taxa found in the surface sediment (Table 5). Chaetoceros and Leptocylindrus danicus were present as resting spores. In addition, benthic marine and freshwater diatoms were also observed in the inner Sound sediments. The average values of the ratio between metals and silicon (mass/mass) in the phytoplankton of the Sound are shown in Table 6. They varied from $0.28(\mathrm{Fe} / \mathrm{Si})$ to $74 \cdot 10^{-6}(\mathrm{Cd} / \mathrm{Si})$. 
The trace metal contents of the phytoplankton are shown in Table 6. Metal contents showed the following range: $0.2-3.8 \mathrm{mgCd} \cdot \mathrm{kg}^{-1}, 7-42 \mathrm{mgCu} \cdot \mathrm{kg}^{-1}, 1.9-9.4 \mathrm{mgFe} \cdot \mathrm{kg}^{-1}, 5-14 \mathrm{mgNi} \cdot \mathrm{kg}^{-1}, 14-26$ $\mathrm{mgPb} \cdot \mathrm{kg}^{-1}, 4-71 \mathrm{mgSi} \cdot \mathrm{kg}^{-1}, 0.3-23-6 \mathrm{mgV} \cdot \mathrm{kg}^{-1}$ and $0.7-0.9 \mathrm{mgZn} \cdot \mathrm{kg}^{-1}$. There was not a spatial trend but a seasonal one, i.e. the highest contents of metals in the phytoplankton were measured in July. In contrast, Si followed chlorophyll concentrations and showed the lowest values in summer. Zinc showed a low seasonal variation in its content. As the variation in metal concentration of phytoplankton was not spatial, results were averaged for the whole Sound by calculating the metal/Si relationship (Table 6).

\section{DISCUSSION}

In order to provide a comprehensive understanding of the behaviour and fate of trace metals in Corcubión Sound the allochthonous contributions, i.e. terrestrial and oceanic, of dissolved and particulate metals are evaluated together with the autochthonous sources, mainly phytoplankton, as well as the temporal rate of accumulation of particulate metal in the sediment.

\subsection{Allochthonous sources of metals in the Sound: anthropogenic and terrestrial influences}

The variations in the dissolved metal levels at Corcubión Inlet may be influenced by the contributions of trace metals due to Cee stream and STP. Freshwater shows concentrations of Co, $\mathrm{Cu}$, and $\mathrm{Zn}$ which are 1-2 orders of magnitude higher than the seawater of the inner Sound. The concentrations of these metals exceed the natural values recorded for pristine rivers (Hart and Hines, 1995). The dissolved metal increase can be related to urban sewage spills (Goldstone et al., 1990a; 1990b), in this case directly from the Corcubión-Cee wastewater plant and indirectly through the Cee stream. On the contrary, $\mathrm{Cd}, \mathrm{Ni}$, and $\mathrm{Pb}$ concentrations were in the same order of magnitude in both, fluvial and marine waters (Table 3). Vanadium is lower in the Inlet due to the influence of riverine input which is depleted in V compared to offshore seawater (3-18 nM, Table 3). This is a common situation in coastal systems (Shiller and Boyle, 1987) such as rias (Prego et al., 2008a).

Particulate $\mathrm{Cu}, \mathrm{Fe}$ and $\mathrm{Ni}$ (Table 4) are higher in the Inlet when compared with the outer Sound. Contents of these metals in SPM of continental origin waters normally exceed those in seawater, especially $\mathrm{Cu}$ and $\mathrm{Fe}$. In this way changes in salinity, $\mathrm{pH}$ and organic ligands play an important role in the adsorption-desorption processes of metals, which vary their dissolvedparticulate concentrations of $\mathrm{Cu}$ and Fe in the estuary (Kogut and Voelker, 2001; Hatje et al., 2003; Powell and Wilson-Finelli, 2003). In the particular case of the Corcubión Inlet, freshwater inputs of $\mathrm{Cu}$ (Tables 3 and 4) may be dominated by supply from the sewage treatment plants (Santos-Echeandía et al., 2008a). Due to flocculation processes associated with iron oxyhydroxides $\mathrm{Cu}$ and $\mathrm{Ni}$ may be enriched in SPM (Eisma, 1986), and deposited into the sediment of the Inlet (Fig.2) as described by Prego et al. (2008b).

These increases of the trace metals concentrations in the Inlet are consistent with the anthropogenic influences. In comparison, other coastal sources of trace metals, such as sediment resuspension (Santos-Echeandía et al., 2012) or diffusion processes at sediment-water interfaces (Santos-Echeandía et al., 2009a), can be unimportant.

There are three main sources for the metals which have accumulated in the sediment of the Sound. Two of these are allochthonous, e.g. the continental lithological and anthropogenic contamination, and the other is of autochthonous origin, which is associated with internal cycling of the phytoplankton in the water column. Atmospheric deposition from land is probably of minor 
importance as the wind mostly blows from the Atlantic Ocean in the northwest area of the Iberian Peninsula (Naranjo and Pérez-Muñunzuri, 2006).

Metal contamination of the surface sediment only occurs with some metals in the inner Sound. The zone most contaminated is the sediment of Corcubión Inlet, near to the harbour of the factory of metallic carbides (St.2 in Fig.2), with levels of $\mathrm{Cu}, \mathrm{Cd}$ and $\mathrm{Zn}$ being triple fold the natural background values. The contamination of $\mathrm{Cu}$ and $\mathrm{Zn}$ in the sedimentary reservoir is typical for shipyard and harbour traffic areas (Mason et al., 2004; Prego et al., 2008c and the references cited therein). Copper comes from ship paints used to prevent the incrustation of seaweeds and $\mathrm{Zn}$ is the component of most protective products against metal corrosion. In Corcubión Inlet a significant source of these metals is the SPM in freshwater run-off (Table 4) as well as diffuse contributions from small shipyard and harbour activities in Cee town.

Lead is remarkable for its wide distribution throughout the Sound sediment as well as by the high levels reached. The contents (Fig.2) rise to 5-fold the background level, calculated from equation (8). However, the outer part of the Sound shows a moderate contamination. It can be hypothesized that these unusually high levels of lead may origin from shipwrecks found in the area around Cape Finisterre and within the Sound. It has been reported that one hundred of merchant and warships have sunk in these waters since $16^{\text {th }}$ century (Patricio-Cortizo, 2000; 2004).

The sediment core was taken close to the mouth of Corcubión Inlet (24 m depth), where hydrographical fronts or pycnoclines inside the Sound may occur as result of shoreline and upwelling development (Varela et al., 2010; Sánchez-Carnero et al., 2011). The frontier zone between the inner and the outer parts of the Sound may be an area of sedimentation of SPM and phytoplankton. The pattern of metal accumulation can be followed throughout the sedimentary record in this area of the Sound. Three layers with distinct sedimentation and metal accumulation rates are differentiated:

(i) The most recent $\left(0.88 \mathrm{~cm} \cdot \mathrm{yr}^{-1}\right)$ shows the highest rate of sedimentations of metals, i.e. 428 and $1190 \mathrm{mg} \cdot \mathrm{m}^{-2} \cdot \mathrm{yr}^{-1}$ of $\mathrm{Cu}$ and $\mathrm{Pb}$, respectively (Table 2). The period of accumulation is coincident with that of the salt marsh burial, Cee stream canalization and changes in the littoral use in the innermost Corcubión Inlet zone.

(ii) A horizon $\left(0.20 \mathrm{~cm} \cdot \mathrm{yr}^{-1}\right)$ deposited during the $20^{\text {th }}$ century, when the mass accumulation rate of the different metals was lower than in the upper unit, i.e. 39 and $75 \mathrm{mg} \cdot \mathrm{m}^{-2} \cdot \mathrm{yr}^{-}$ ${ }^{1}$ of $\mathrm{Cu}$ and $\mathrm{Pb}$, respectively. This period is coincident with the development of the harbour and factory of metallic carbides in Cee, which was inaugurated in 1903.

(iii) The lower unit represents the pre-industrial period from $14^{\text {th }}$ to $19^{\text {th }}$ centuries $(0.08$ $\mathrm{cm} \cdot \mathrm{yr}^{-1}$ ) and is characterized by the lowest sedimentation rates of metals, i.e. 7 and $16 \mathrm{mg} \cdot \mathrm{m}^{-2} \cdot \mathrm{yr}^{-1}$ of $\mathrm{Cu}$ and $\mathrm{Pb}$, respectively.

The temporal ranges observed vertically in the core from the Sound are similar to sedimentation rates calculated in various parts of the Ria of Vigo (Evans et al., 2011). In the upper part of the core sedimentation rates were in the range of those found for the inner Ria of Vigo, whilst those of the intermediate core unit were similar to those in the middle Ria. Sediment contamination by $\mathrm{Cd}, \mathrm{Cu}, \mathrm{Pb}$ and $\mathrm{Zn}$ was detected during the periods of anthropogenic influence, i.e. the $20^{\text {th }}$ century. Metals in industrialized rias such as Ferrol (Cobelo-García and Prego, 2003) and Vigo (Alvarez-Iglesias et al., 2007) showed similar core trends with an increase of metal content toward the present years. In the core of Sound contamination doubled the $\mathrm{Cd}$ and $\mathrm{Cu}$ content in the sediments during the last 20 and 50 years, respectively, while $\mathrm{Pb}$ and $\mathrm{Zn}$ tripled from 75 and 50 years ago, respectively. 


\subsection{Allochthonous sources of metals in the Sound: oceanic influence}

The seasonally measured concentrations of dissolved trace metals concentrations in the outer Corcubión Sound (Table 3) are within the range of concentrations observed in several studies of the north-eastern Atlantic Ocean (Middelburg et al., 1988; Donat and Bruland, 1995; Landing et al., 1995; Saager et al., 1997; Ellwood and van der Berg, 2000; Cotté-Krief et al., 2000). Nevertheless, the $\mathrm{Ni}$ and $\mathrm{Pb}$ levels in the Sound are slightly higher than the highest measured values in Open Ocean (3.6 nM and $0.22 \mathrm{nM}$, respectively). Santos-Echeandía et al. (2009b) described seasonal dynamics of $\mathrm{Cd}, \mathrm{Co}, \mathrm{Cu}, \mathrm{Ni}, \mathrm{Pb}, \mathrm{V}$ and $\mathrm{Zn}$ in coastal waters of the northwestern Iberian Peninsula. They showed that the subsurface waters (10-100 $\mathrm{m}$ depth) offshore of the Ria of Vigo showed yearly average concentration similar to those of the outer Sound, except for $\mathrm{Cd}$ and $\mathrm{Pb}$ which had values which were a little lower, $0.048 \pm 0.026 \mathrm{nM}$ and $0.13 \pm 0.09 \mathrm{nM}$, respectively (Santos-Echeandía et al., 2009b).

The pristine pattern of trace metals in the Sound, except for the human impact in the innermost part is also highlighted by comparison with the values which have been determined in other European coastal system which have suffered anthropogenic impact. French $(\mathrm{Cu}, \mathrm{Pb}, \mathrm{Ni}, \mathrm{Zn}$; Chiffoleau et al., 1999; Monbet, 2006) and English (Co, Cu, Pb, Ni, Zn; Laslett, 1995; Martino et al., 2002) estuaries and marine adjacent areas as well as those of the southwestern Spanish coast ( $\mathrm{Cd}$, $\mathrm{Cu}, \mathrm{Zn}$; van Geen et al., 1991; Elbaz-Poulichet et al., 2001) show higher levels of the investigated metal than the waters of the Sound.

The pristine conditions and the presence of upwelling, mainly in the outer Sound, make it feasible for the first time, to estimate the dissolved metal concentrations in the Galician coastal upwelling. Even though nutrient salts in the Galician upwelling have been profusely investigated (Prego et al., 1999 and references cited therein) since the pioneering work by Fraga (1981), the dissolved trace metal concentrations and their biogeochemical cycle in the ENACW upwelling was an outstanding issue. The dissolved metal information from the Sound during the upwelling in May was discarded because it was not an intense event. The winter upwelling episode could be also discarded because the upwelled water in that season is not ENACW (Prego et al., 2007). However, this was not the case of the upwelling event in February because, according to the TS diagram (Fig.6) during this period, the upwelled water is ENACW. Therefore, the dissolved metal concentrations in February can be considered, as in the case of July as characteristics of the EMACW upwelling. Consequently, and considering those two upwelling episodes in the Sound, the mean concentrations of dissolved metals associated to the ENACW were: $0.07 \pm 0.03 \mathrm{nM}$ of $\mathrm{Cd}$, $0.11 \pm 0.02 \mathrm{nM}$ of $\mathrm{Co}, 2.6 \pm 1.6 \mathrm{nM}$ of $\mathrm{Cu}, 4.6 \pm 0.6 \mathrm{nM}$ of $\mathrm{Ni}, 0.20 \pm 0.10 \mathrm{nM}$ of Pb, $31 \pm 2 \mathrm{nM}$ of $\mathrm{V}$ and 3.8 $\pm 2.3 \mathrm{nM}$ of $\mathrm{Zn}$. By comparison in May 2005 (Table 3), when the upwelling event was not as intense as in February or July 2005, the concentration of Cd, Co, Pb and $\mathrm{Zn}$ in the outer Sound were comparable to the ENACW.

This initial estimation of dissolved trace metals in the Galician coastal upwelling can be compared with that obtained by Cotté-Krief et al. (2000): $\mathrm{Cd}(0.03-0.08 \mathrm{nM}), \mathrm{Cu}(0.7-1.8 \mathrm{nM}), \mathrm{Ni}$ (1.8-3.9 $\mathrm{nM})$ and $\mathrm{Zn}(0.9-4.3 \mathrm{nM})$ from surface samples of upwelled ENACW off the southern coast of Portugal $\left(37.5-38.5^{\circ} \mathrm{N}\right)$. The concentrations obtained are within the range $(\mathrm{Cd}$ and $\mathrm{Zn})$ or slightly lower $(\mathrm{Cu}$ and $\mathrm{Ni}$ ) than those obtained in the present study. Comparable concentrations of dissolved metals in ENACW waters as those of the Sound are found in other regions as the middle Atlantic and Celtic Sea, e.g. $\mathrm{Cd}$ and Pb, but lower for Ni and Cu (Brügmann et al., 1985; Lambert et al., 1991; Saager et al., 1997; Cotté-Krief et al., 2002). The present study in the Corcubión Sound represents a step forward, but more research of trace metals levels and their biogeochemical processes in the Galician upwelling is necessary. 


\subsection{Autochthonous domain on metals in the Sound}

Phytoplankton is the main autochthonous source of metals in the study area. The Sound becomes eutrophic during the upwelling episodes (Varela et al., 2010) which is typical for upwelling regions (Summerhayes et al., 1995). A phytoplanktonic succession develops throughout the year (Casas et al., 1999) and the dominant diatom species typical of blooms change seasonally (Figueiras and Niell, 1987; Casas et al, 1999; Varela et al. 2010). This change was observed in the three seasonal upwelling events in the Sound. Lauderia borealis, typical species of early blooms, was present in the winter bloom, while Leptocylindrus danicus and Pseudonitzschia spp were dominant during summer blooms, as usually occurs in Galician waters (Figueiras and Niell, 1987; Varela et al., 2001). Both, the inner and the outer Sound showed similar species compositions during samplings (Table 5). Phytoplankton take up dissolved trace metals from its environment, either by assimilation or by adsorption to cell surface (Hassler et al., 2004). While the metal adsorption is interpreted in terms of surface complex formation equilibria (Xue et al., 1988), the absorption is showed in the phytoplankton stoichiometry of the essential trace elements (Morel, 2008). Consequently, the dominant diatoms species may be associated to the average metal content of bioactive metals, which are normalized to Si (Table 6), the main constituent of the diatoms cell wall. Metal content ratios in diatoms were of $0.2 / 2 / 1 / 2 / 1$ for $\mathrm{Cd} / \mathrm{Cu} / \mathrm{Ni} / \mathrm{Pb} / \mathrm{V}$ and $16 / 55 / 1$ for $\mathrm{Fe} / \mathrm{Si} / \mathrm{Zn}$ respectively. Morel et al. (2003) averaging the Ho et al. (2003) data presented an extension to the Redfield formula including metals with a ratio of 10 for $\mathrm{Fe} / \mathrm{Zn}$ and $1 / 2$ for $\mathrm{Cd} / \mathrm{Cu}$ for cultures of marine phytoplankton. The differences found when these are compared with data from the Sound, mainly the high (one order of magnitude higher) Fe/Zn ratio, may be the result of different species composition, distinct growing conditions (field observation and laboratory cultivations), and the analyses of total cellular metals in the samples from the Sound (washing agents were not used to distinguish adsorbed and absorbed metals following Hassler and Schoemann, 2009).

When diatoms from a bloom sink to the bottom of the Sound, this autochthonous fraction and its metal content mixes with the allochthonous sediments and its metals. Remineralisation in the water column may return the trace metals to the seawater, however during the Galician upwelling, the remineralisation of particulate matter mainly occurs at 120-150 m depth (Prego and Bao, 1997), and therefore this process is of minor importance in the Sound.

The Metal/Si ratios of diatoms can be compared with the same ratio in the biogenic opal at the sediment surface (Table 6). The results show two different groups. One group shows high Metal/Si ratio, indicating a prevailing allochthonous, lithogenic and anthropogenic, source of metals as $\mathrm{Cu}, \mathrm{Fe}, \mathrm{Ni}, \mathrm{Pb}$ and $\mathrm{V}$. The other, with low ratios, shows the relevant influence of diatoms registered by the $\mathrm{Cd}$ and $\mathrm{Zn}$ metal content of sediments.

Metal contents in coastal sediments have a predominant continental origin, for this reason metals are usually normalized using a lithogenic element, e.g. Al (Loring, 1991), to define their background values. So, the high metal/Al correlations $(r \geq 0.9)$ of background equations (4) to (9) show the continental landmasses as the main sources of $\mathrm{Co}, \mathrm{Cu}, \mathrm{Fe}, \mathrm{Ni}, \mathrm{Pb}$ and $\mathrm{V}$ in the preindustrial sediments of the Sound. The exceptions were $C d$ and $Z n$, eq. (3) and (10), respectively. The lower correlation ( $r=0.77$ ) of $\mathrm{Zn} / \mathrm{Al}$ suggests a partial influence of a pre-industrial source not subordinated to the continental contributions. This source is dominant in the case of $\mathrm{Cd}$ because $\mathrm{Cd}$ background level is not dependent on Al content: $[\mathrm{Cd}]=0.26 \pm 0.04 \mathrm{mg} \cdot \mathrm{kg}^{-1}$. In the Finisterre upwelling region the uncontaminated sediments of the Ria of Vigo already showed a negative $\mathrm{Cd} / \mathrm{Al}$ background correlation (Prego et al., 2008b), which also indicated a non-terrestrial $\mathrm{Cd}$ input. Sedimentary $\mathrm{Cd}$ content is enhanced because biodetritus are typically enriched in this metal (Collier and Edmond, 1984) as occurs in the Chilean upwelling sediments (Böning et al., 
2005) and to a greater extent in the Peruvian perennial upwelling (Böning et al., 2004). Thus, an autochthonous origin seems to be the main source of $\mathrm{Cd}$ in the sediments of Corcubión Sound.

\section{CONCLUSION: trace metals at the land-sea boundary}

The coastal boundary zone between the terrestrial and marine domains of the Sound of Corcubión is divided into two differently influenced areas. The outer Sound shows seawater signatures, while the Corcubión Inlet may be influenced by trace metal input from terrestrial and anthropogenic sources. Different trends in three seasonal samplings were observed:

(i) Some dissolved trace metals such as $\mathrm{Cd}, \mathrm{Ni}$ and $\mathrm{Pb}$ show similar concentrations in both, Inlet and outer Sound waters.

(ii) Dissolved $V$ is lower in the Inlet waters due to the influence of riverine input which is depleted in $\mathrm{V}$ in comparison to offshore seawater.

(iii) Cobalt, $\mathrm{Cu}$ and $\mathrm{Zn}$ concentrations (and $\mathrm{Cu}$ content in SPM) are higher in the Inlet water in comparison to the outer Sound due to the terrestrial input to the Inlet.

For this reason the interaction between the land and ocean causing metal contributions to the Sound is restricted to the innermost shallow zones where the allochthonous anthropogenic activities supply dissolved $\mathrm{Co}, \mathrm{Cu}$ and $\mathrm{Zn}$ and particulate $\mathrm{Cd}, \mathrm{Cu}, \mathrm{Fe}$ and $\mathrm{Zn}$. Metal contamination of $\mathrm{Cd}, \mathrm{Cu}, \mathrm{Pb}$ and $\mathrm{Zn}$, was observed spatially in the Corcubión Inlet, and also with time increasing during the industrial period, i.e. the last century. In this system phytoplankton is the main autochthonous source of metals to the sediment. However, metal/silicon ratios pointed a prevailing allochthonous, lithogenic and anthropogenic, source of $\mathrm{Cu}, \mathrm{Fe}, \mathrm{Ni}, \mathrm{Pb}$ and $\mathrm{V}$ to the sedimentary reservoir. In contrast, an autochthonous origin, i.e. settling of diatoms, can be indicated for the $\mathrm{Cd}$ contents of the sediments of Corcubión Sound.

The Corcubión Sound is a coastal system where oceanic conditions are prevailing under the influence of upwelling events throughout all the year. Metals cycles in the northeaster Atlantic coastal zone of Finisterre are less disturbed by anthropogenic activity in comparison with other world regions, such as semi-closed seas (e.g. the North Sea) or coasts with significant fluvial contributions (e.g. Humber, Tagus or Loira Rivers). Hence, the Sound system is relatively pristine and may be used as a reference for natural trace-metal processes along the Atlantic coasts.

Acknowledgements. Authors are grateful to the crew of R/V Lura for their kind cooperation during the samplings, to J. Lorenzo, A. Roura, P. Ferro and I. González for their technical assistance, to the employers of wastewater treatment plant of Cee town for sewage sampling, to Prof. J.M. Jouanneau (CNRS) for core dating, to Dr. M. Cabanas (IEO) for UI index, to two anonymous referees for their detailed and valuable comments, and to Prof. G. Evans (School of Ocean and Earth Science, Univ. of Southampton) for his valuable review of the English language. This work is a contribution to the LOICZ-Spain program and it was supported by the Special Research Action of the Spanish CICYT "Reconocimiento Oceanográfico en la época de floración primaveral en la zona de Cabo Finisterre (Galicia, Costa de La Muerte) en relación con el vertido del Prestige" in cooperation with the research project "Land-sea exchange of trace metals and its importance for marine phytoplankton in an upwelling coast (acronym: MITOFITO)", ref. CTM201128792-C02, financed by the Spanish "Ministerio de Economía y Competitividad". 


\section{REFERENCES}

Abrantes, F., Gil, I., Lopes, C., Castro, M., 2005a. Quantitative diatom analyses-a faster cleaning procedure. Deep-Sea Res. I 52, 189-198.

Abrantes, F. Lebreiro, S. Rodrigues, T. Gil, I. Bartels-Jónsdóttir, H. Oliveira, P. Kissel, C. and Grimalt, J.O., 2005b. Shallow-marine sediment cores record climate variability and earthquake activity off Lisbon (Portugal) for the last 2000 years. Quaternary Sci. Rev. 24, 2477-2494.

Achterberg, E.P., van den Berg, C.M.G., 1994. In-line ultraviolet-digestion of natural-water samples for trace-metals determination using an automated voltammetric system. Anal. Chim. Acta 291, 213-232.

Álvarez-Iglesias, P., Quintana, B., Rubio, B., Arlucea, M., 2007. Sedimentation rates and trace metal input history in intertidal sediments from San Simón Bay (Ría de Vigo, NW Spain) derived from $210 \mathrm{~Pb}$ and $137 \mathrm{Cs}$ chronology. J. Environ. Radioactiv. 98, 229-250.

Auger Y., Bodineau L., Leclerq S., Wartel M., 1999. Some aspects of vanadium and chromium chemistry in the English Channel. Cont. Shelf Res. 19, 2003-2018.

Bakun, A., 1973. Coastal upwelling indices, West Coast of North America, 1946-1971, NOAA Technical Report NMFS SSRF-671, US Department of Commerce.

Bernárdez, P. Prego, R., Francés, G., González-Álvarez, R., 2005. Opal content in the Ría de Vigo and Galician continental shelf: biogenic silica in the muddy fraction as an accurate paleoproductivity proxy. Cont. Shelf Res. 25, 1249-1264.

Bernárdez, P., Prego, R., Varela, M. and Francés, G., 2008. Diatom thanatocoenosis in a middle Galician ría. Spatial patterns and their relationship to the seasonal diatom cycle in the water column and hydrographic conditions. Cont. Shelf Res. 28, 2496-2508.

Bianchi, T.S., 2007. Biogeochemistry of estuaries. Oxford University Press, Oxford.

Böning, P., Brumsack, H.-J., Böttcher, M.E., Schnetger, B., Kriete, C., Kallmeyer, J., Borchers, S.L., 2004. Geochemistry of Peruvian nearsurface sediments. Geochim. Cosmochim. Acta 68, 4429-4451.

Böning, P., Cuypers, S., Grunwald, M., Schnetger, B., Brumsack, H.J., 2005. Geochemical characteristics of Chilean upwelling sediments at similar to 36 degrees S. Mar. Geol. 220, 121.

Brügmann, L., Danielsson, L.-G., Magnusson, B., Werstelung, S., 1985. Lead in the North Atlantic Ocean. Mar. Chem. 16, 47-60.

Bruland, K.W., Lohan, M.C., 2003. Controls of trace metals in seawater, in: Elderfield, H. (Ed.), Treatise on Geochemistry. Elsevier, Oxford, pp. 23-47.

Casas, B., Varela, M., Bode, A., 1999. Seasonal succession of phytoplankton species in the coast of La Coruña (Galicia, NW of Spain). Bol. Inst. Esp. Oceanogr. 15, 413-429.

Chiffoleau, J.F., Auger, D., Chartier, E., 1999. Fluxes of selected trace metals from the Seine estuary to the eastern English Channel during the period August 1994 to July 1995. Cont. Shelf Res. 19, 2063-2082.

Cobelo-García, A., Prego, R., 2003. Heavy Metal Sedimentary Record in a Galician Ria (NW Spain): Background Values and Recent Contamination. Mar. Pollut. Bull. 46, 1253-1262.

Cobelo-García, A., Prego, R., 2004. Land inputs of trace metals, major elements, particulate organic carbon, and suspended solids to an industrial coastal bay of the NE Atlantic. Water Res. 38, 1753-1764.

Cobelo-García, A., Prego, R., deCastro, M., 2005a. Metal distribution and their fluxes at the coastal boundary of a semi-enclosed ria. Mar. Chem. 97, 277-292. 
Cobelo-Garcia, A., Santos-Echeandia, J., Prego, R., 2005b. Direct simultaneous determination of $\mathrm{Cu}, \mathrm{Ni}$ and $\mathrm{V}$ in seawater using adsorptive cathodic stripping voltammetry with mixed ligands. Electroanal. 17, 906-911.

Collier, R., Edmond, J., 1984. The trace element geochemistry of marine biogenic particulate matter. Prog. Oceanogr. 13, 113-199.

Cotté-Krief, M.-H., Guieu, C., Thomas, A.J., Martin, J.-M., 2000. Sources of $\mathrm{Cd}, \mathrm{Cu}, \mathrm{Ni}$ and $\mathrm{Zn}$ in Portuguese coastal waters. Marine Chemistry 71, 199-214.

Cottè-Krief, M.H., Thomas, A.J., Martin, J.M., 2002. Trace metal (Cd, Cu, Ni and Pb) cycling in the upper water column near the shelf edge of the European continental margin (Celtic Sea). Mar. Chem. 79, 1-26.

Donat, J.R., Bruland, K.W., 1995. Trace Elements in the Oceans, in: Salbu, B., Steinnes, E. (Eds.), Trace Elements in Natural Waters. CRC Press, Boca Raton (FL), pp. 247-281.

Elbaz-Poulichet, F., Braungardt, C., Achterberg, E., Morley, N., Cossa, D., Beckers, J.M., Nomerange, P., Cruzado, A., Leblanc, M., 2001. Metal biogeochemistry in the Tinto-Odiel Rivers (Southern Spain) and in the Gulf of Cadiz: a synthesis of the results of TOROS project. Cont. Shelf Res. 21, 1961-1973.

Ellwood, M.J., van den Berg, C.M.G., 2000. Zinc speciation in the Northeastern Atlantic Ocean. Mar. Chem. 68, 295-306.

EPA, 1996. Method 3052. Microwave assisted acid digestion of siliceous and organically based matrices. http: //www.epa.gov/epaoswer/hazwaste/test/3052.pdf>

Eisma, D., 1986. Flocculation and re-flocculation of suspended matter in estuaries. Neth. J. Sea Res. 20, 183-199.

Evans, G., Prego, R., 2003. Rias, estuaries and incised valleys: is a ria an estuary? Mar. Geol. 196, 171-175.

Evans, G., Prego, R., Marshall, J.E., 2011. Organic matter in ria sediments: relevance of terrestrial sources and temporal variations in rates of accumulation. Est. Coast. Shelf Sci. 94, 246-254.

Fatela, F., Taborda, R., 2002. Confidence limits of species proportions in microfossil assemblages. Mar. Micropaleontol. 45, 169-174.

Figueiras, F.G., Niell, F.X., 1987. Distribuciónestacional y espacial del fitoplancton en la ría de Pontevedra (NO de España). Inv. Pesq. 51, 293-320.

Filgueiras, A.V., Prego, R., 2007. Biogeochemical fluxes of iron from rainwater, rivers and sewage to a Galician Ria (NW Iberian Peninsula). Natural versus anthropogenic contributions. Biogeochemistry 86, 319-329.

Fraga, F., 1981. Upwelling off the Galician Coast, Northwest Spain, in: Richards, F.A. (Ed.), Coastal Upwelling. American Geophysical Union, Washington DC, pp. 176-182.

GEOTRACES Planning Group, 2006. GEOTRACES Science Plan. Baltimore, Maryland: Scientific Committee on Oceanic Research.

Goldstone, M.E., Kirk, P.W.W., Lester, J.N., 1990a. The behaviour of heavy metals during wastewater treatment I. Cadmium, chromium and copper. Sci. Total Environ. 95, 233-252.

Goldstone, M.E., Kirk, P.W.W., Lester, J.N., 1990b. The behaviour of heavy metals during wastewater treatment II. Lead, nickel and zinc. Sci. Total Environ. 95, 253-270.

Hakanson, L., 1980. An ecological risk index for aquatic pollution control. A sedimentological approach. Water Res. 14, 975-1001.

Hansen H.P., Grasshoff, K., 1983. Automated chemical analysis, in: Grasshoff, K., Ehrhardt, M., Kremling, K. (Eds), Methods of Seawater Analysis. Verlag Chemie, Weinhein, pp. 368-376. 
Hanson, P.J., Evans, D.W., Colby, D.R., 1993. Assessment of elemental contamination in estuarine and coastal environments based on geochemical and statistical modeling of sediments. Mar. Environ. Res. 36, 237-266.

Hart, B.T., Hines, T., 1995. Trace elements in rivers, in: Salbu, B., Steinnes, E. (Eds.), Trace Elements in Natural Waters. CRC Press, Boca Raton (FL) pp. 203-221.

Hasle, GR., Syvertsen, E.E., 1996. Marine Diatoms, in: Tomas, C.R., Hasle, G.R., Syvertsen, E.E., Steidinger, K.A., Tangen, K., (Eds.). Identifying Marine Diatoms and Dinoflagellates. Academic Press, New York, pp. 5-385.

Hassler, C.S., Slaveykova, V.I., Wilkinson, K.J., 2004. Discriminating between intra- and extracellular metals using chemical extractions. Limnol. Oceanogr. Methods 2, 237-247.

Hassler, C.S., Schoemann, V., 2009. Discriminating between intra- and extracellular metals using chemical extractions: an update on the case of iron Limnol. Oceanogr.: Methods 7, 479-489.

Hatje, V., Payne, T.E., Hill, D.M., McOrist, G., Birch, G.F., Szymczak, R., 2003. Kinetics of trace element uptake and release by particles in estuarine waters: Effects of $\mathrm{pH}$, salinity, and particle loading. Environ. Int. 29, 619-629.

Ho T.-Y., Quigg A., Finkel Z.V., Milligan A.J., Wyman K., Falkowski P.J., Morel F.M.M. 2003. The elemental composition of some marine phytoplankton. J. Physol. 39, 1445-1459.

Howard, A.G., Statham, P.J., 1993. Inorganic trace analysis: Philosophy and practice. Wiley, Chichester.

Hughen, K.A. Baillie, M.G.L. Bard, E. Beck, J.W. Bertrand, C. Blackwell, P.G. Buck, C.E. Burr, G.S. Cutler, K.B. Damon, P.E. Edwards, R.L. Fairbanks, R.G. Friedrich, M. Guilderson, T.P. Kromer, B. McCormac, G. Manning, S. Ramsey, C.B. Reimer, P.J. Reimer, R.W. Remmele, S. Southon, J.R. Stuiver, M. Talamo, S. Taylor, F.W. van der Plicht, J., Weyhenmeyer, C.E., 2004: Marine04 Marine Radiocarbon Age Calibration, 0-26 Cal kyr BP. Radiocarbon 46, 1059-1086.

Kay, R., Alder, J., 2005. Coastal Planning and Management, second ed. E \& FN Spon, London.

Kogut, M.B., Voelker, B.M., 2001. Strong copper-binding behaviour of terrestrial humic substances in seawater. Environ. Sci. Technol. 35, 1149-1156.

Lambert, C.E., Nicolas, E., Veron, A., Buat-Menard, P., Klinkhammer, G., Le Corre, P., Morin, P., 1991. Anthropogenic lead cycle in the northeastern Atlantic. Oceanol. Acta 14, 59-66.

Landing, W.M., Cutter, G.A., Dalziel, J.A., Flegal, A.R., Powell, R.T., Schmidt, D., Shiller, A., Statham, P., Westerlund, S., Resing, J., 1995. Analytical intercomparison results from the 1990 intergovernmental oceanographic commission openocean baseline survey for trace metals: Atlantic Ocean. Mar. Chem. 49, 253-265.

Laslett, R.E., 1995. Concentrations of dissolved and suspended particulate $\mathrm{Cd}, \mathrm{Cu}, \mathrm{Mn}, \mathrm{Ni}, \mathrm{Pb}$ and $\mathrm{Zn}$ in surface waters around the coasts of England and Wales and in adjacent seas. Est. Coast. Shelf Sci. 40, 67-85.

Lesueur P., Jouanneau J.M., Boust D., Tastet J.P., Weber O., 2001. Sedimentation rates and fluxes in the continental shelf mud fields in the Bay of Biscay (France). Cont. Shelf Res. 21, 13831401.

Loring, D.H., 1991. Normalization of heavy-metal data from estuarine and coastal sediments. ICES J. Mar. Sci. 48, 101-115.

Loring, D.H., Rantala, R.T.T., 1992. Manual for the geochemical analyses of marine sediments and suspended particulate matter. Earth-Sci. Rev. 32, 235-283.

Luoma, S.N., Dagovitz, R., Axtaman, E., 1990. Temporally intensive study of trace metals in sediments and bivalves from a large river-estuarine system: Suisun Bay/Delta in San Francisco Bay. Sci. Total Environ. 97/98, 685-712. 
Martino, M., Turner, A., Nimmo, A., Millward, G.E., 2002. Resuspension, reactivity and recycling of trace metals in the Mersey Estuary, UK. Mar. Chem. 77, 171-186.

Mason, R.P., Kim, E.H., Cornwell, J., 2004. Metal accumulation in Baltimore Harbor: current and past inputs. Appl. Geochem. 19, 1801-1825.

Middelburg, J.J., Hoede, D., van der Sloot, H.A., van der Weijden, C.H., Wijkstra, J., 1988. Arsenic, antimony and vanadium in the north-Atlantic Ocean. Geochim. Cosmochim. Acta 52, 28712878.

Monbet, P., 2006. Mass balance of lead through a small macrotidal estuary: the Morlaix River estuary (Brittany, France). Mar. Chem. 98, 59-80.

Morel, F.M.M., 2008. The co-evolution of phytoplankton and trace element cycles in the oceans. Geobiology 6, 318-324.

Morel, F.M.M., Price, N.M., 2003. The biogeochemical cycles of trace metals in the oceans. Science 300, 944-947.

Morel, F.M.M., Milligan, A.J. and Saito, M.A., 2003. Marine bioinorganic chemistry: The role of trace metals in the oceanic cycles of major nutrients, in: Elderfield, H. (Ed.), Treatise on Geochemistry. Elsevier, Oxford, pp. 113-143.

Mortlock, R.A., Froelich, P., 1989. A simple method for the rapid determination of biogenic opal in pelagic marine sediments. Deep-Sea Res. 36, 1415-1426.

Naranjo, L., Pérez-Muñunzuri, V., 2006. A variabilidade natural do clima en Galicia. Xunta de Galicia, Santiago.

Neal, C., Smith, C.J., Jeffery, H.A., Jarvie, H.P., Robson, A.J., 1996. Trace element concentrations in the major rivers entering the Humber estuary, NE England. J. Hydrol. 182, 37-64.

Neveux, J., Panouse, M., 1987. Spectrofluorometric determination of chlorophylls and pheophytins. Arch. Hydrobiol. 109, 567-581.

Patricio-Cortizo, F., 2000. Historia da costa gallega e os seus naufraxios: séculos I a XIX. Edicios Lea, Santiago de Compostela.

Patricio-Cortizo, F., 2004. Historia da costa gallega e os seus naufraxios: século XX. Edicios Xerais, Vigo.

Powell, R.T., Wilson-Finelli, A., 2003. Importance of organic Fe complexing ligands in the Mississippi River plume. Est. Coast. Shelf Sci. 58, 757-763.

Prange, A., Kremling, K., 1985. Distribution of dissolved molybdenum, uranium and vanadium in Baltic Sea waters. Mar. Chem. 16, 259-274.

Prego, R., Bao, R., 1997. Upwelling influence on the Galician coast: silicate in shelf water and underlying surface sediments. Cont. Shelf Res. 17, 307-318.

Prego, R., Barciela, C., Varela, M., 1999. Nutrient dynamics in the Galician coastal area (Northwestern Iberian Peninsula): Do the Rias Bajas receive more nutrient salts than the Rias Altas? Cont. Shelf Res. 19, 317-334.

Prego, R., Cobelo-García, A., 2003. $20^{\text {th }}$ Centrury overview of Heavy Metals in the Galician Rias (NW Iberian Peninsula). Environ. Pollut. 121, 425-452.

Prego, R., Cotté, M.-H., Cobelo-García, A., Martin, J.-M., 2006. Trace metals in the water column of the Vigo Ria: Offshore exchange in mid-winter conditions. Est. Coast. Shelf Sci. 68, 289296.

Prego, R., Guzman-Zuñiga, D., Varela, M., deCastro, M., 2007. Consequences of winter upwelling events on biogeochemical and phytoplankton patterns in a western Galician ria (NW Iberian Peninsula). Est. Coast. Shelf Sci. 73, 409-422. 
Prego R., Santos-Echeandía J., Cobelo-García A., 2008a. Letter to the editor re: Villares et al., 2007; on the impact of the Prestige oil spill on the levels of vanadium and other trace elements along the coast of Galicia (NW Iberian Peninsula). Sci. Total Environ. 399, 216-218.

Prego R., Filgueiras A.V., Santos-Echeandía J., 2008b. Temporal and spatial changes of total and labile metal concentration in the surface sediments of the Vigo Ria (NW Iberian Peninsula): Influence of anthropogenic sources. Mar. Pollut. Bull. 56, 1022-1042.

Prego R., Ferro P., Trujillo C., 2008c. Lead and Zinc contamination of surface sediments in the main harbours of the Galician Rias. J. Iberian Geol. 34, 243-252.

Saager, P.M., deBaar, H.J.W., deJong, J.T.M., Nolting, R.F., Schijf, J., 1997. Hydrography and local sources of dissolved trace metals $\mathrm{Mn}, \mathrm{Ni}, \mathrm{Cu}$, and $\mathrm{Cd}$ in the northeast Atlantic Ocean. Mar. Chem. 57, 195-216.

Salomons, W., Kerdijk, H., Van Pagee, H.Y., Schreur, A., 1985. Behaviour and impact assessment of heavy metals in estuarine and coastal zones, in: Seeliger, U., De Lacerda, L.D., Patchineelam, S.D. (Eds.), Metals in Coastal Environments of Latin America. Springer-Verlag, Berlin, pp. 157198.

Sánchez-Carnero, N., Couñago, E., Rodríguez-Pérez, D., Freire, J., 2011. Exploiting oceanographic satellite data to study the small scale coastal dynamics in a NE Atlantic open embayment. J Mar. Syst. 87, 123-132.

Santos-Echeandia, J., Laglera, L.M., Prego, R., van den Berg C.M.G., 2008. Copper speciation in continental inputs to the Vigo Ria: Sewage discharges versus river fluxes. Mar. Pollut. Bull. 56, 308-317.

Santos-Echeandía, J., Prego, R., Cobelo-García, A., Millward, G.E., 2009a. Porewater geochemistry in a Galician Ria (NW Iberian Peninsula): Implications for benthic fluxes of dissolved trace elements (Co, Cu, Ni, Pb, V, Zn). Mar. Chem. 117, 77-87.

Santos-Echeandia, J., Prego, R., Cobelo-García, A., 2009b. Intra-annual variation and baseline concentrations of dissolved trace metals in the Vigo Ria and adjacent coastal waters (NE Atlantic Coasat). Mar. Pollut. Bull. 58, 299-304.

Santos-Echeandía, J., Prego, R., Cobelo-García, A., Caetano, M., 2012. Metal composition and fluxes of sinking particles and post-depositional transformation in a ria coastal system (NW Iberian Peninsula). Mar. Chem. 134-135, 36-46.

Schrader, H., Gersonde, R., 1978. Diatoms and silicoflagellates. Utretch Micropaleontol. Bull. 17, 129-176.

Shiller AM, Boyle EA., 1987. Dissolved vanadium in rivers and estuaries. Earth Planet. Sci. Lett. 86, 214-224.

Smith, S.V., Buddemeier, R.W., Wulff, F., Swaney, D.P., 2005. C, N, P fluxes in the coastal zone, in: Crossland, C.J., Kremer, H.H., Lindeboom, H.J., Marshall-Crossland, J.I., LeTissier, M.D.A. (Eds.), Coastal fluxes in the Anthropocene. Springer, Berlin, pp. 95-144.

Stuiver, M., Reimer, P.J., 1993. Extended ${ }^{14} \mathrm{C}$ database and revised CALIB radiocarbon calibration program. Radiocarbon 35, 215-230.

Summerhayes, C.P. Emeis, K.-C., Angel, M.V., Smith, R.L., Zeitzschel, B., 1995. Upwelling in the Ocean. Modern process and ancient records. Wiley, Chichester.

Tanner, P.A., Leong, L.S., Pan, S.M., 2000. Contamination of heavy metals in marine sediment cores from Victoria Harbour, Hong Kong. Mar. Pollut. Bull. 40, 769-779.

Tomas, C.R., 1997. Identifying marine phytoplankton. Academic Press, New York.

UNESCO, 1994. Protocols for the Joint Global Ocean Flux Study (JGOFS) core measurements. Manuals and Guides 29, 1-170. 
van Geen, A., Boyle, E.A., Moore, W.S., 1991. Trace-metal enrichments in waters of the Gulf of Cadiz, Spain. Geochim. Cosmochim. Acta 55, 2173-2191.

Varela, M., Prego, R., Belzunce, M.J., Martín-Salas, F., 2001. Inshore-offshore differences in seasonal variations of phytoplankton assemblages: the case of a Galician Ria Alta (A Coruña Ria) and its adjacent shelf (NW Spain). Cont. Shelf Res. 21, 1815-1838.

Varela, M., Prego, R., Pazos, Y., 2004. Vertical biogenic particulate flux in a Galician Ria (NW Spain). Mar. Ecol-Prog. Ser. 269, 17-32.

Varela, M., Álvarez-Ossorio M.T., Bode A., Prego, R., Bernárdez, P., Garcia-Soto, C., 2010. The effects of a winter upwelling on biogeochemical and planktonic components in an area close to the Galician Upwelling Core: The Sound of Corcubión (NW Spain). J. Sea Res. 64, 260-272.

Wehrli, B., Stumm, W., 1989. Vanadyl in natural waters: Adsorption and hydrolysis promote oxygenation. Geochim. Cosmochim. Acta 53, 69-77.

Windom, H., Schropp, S.J., Calder, F.D., Ryan, J.D., Smith, R.G., Burney, L.C., Lewis, F.G., Rawlinson, C., 1989. Natural trace metal concentrations in estuarine and coastal marine sediments of the Southeastern United States. Environ. Sci. Technol. 23, 314-320.

Witkowski, A., Lange-Bertalot, H., Metzeltin, D., 2000. Diatom Flora of Marine Coasts I. Iconographia Diatomologica Vol. 7. A.R.G. Gantner Verlag K.G., Ruggell, Liechtenstein

Xue, H.-B., Stumm, W., Sigg, L., 1988. Binding of heavy metal to algal surfaces. Water Res. 22, 917926.

Yeats, P.A., 1992. The distribution of dissolved vanadium in eastern Canadian coastal waters. Est. Coast. Shelf Sci. 34, 85-93.

\section{TABLE AND FIGURE CAPTIONS}

Figure 1. Water and sediment sampling stations of the Corcubión Sound. In the water map black circles correspond with CTD stations and empty points with freshwater stations. In the sediment map black circles correspond with surface sediment stations, black cross with the core sampling point and the broken line shows the main channel of the Sound.

Figure 2. Metal content in the surface sediment along the main channel of the Corcubión Sound.

Figure 3. Vertical profile of ${ }^{210} \mathrm{~Pb}$ activity in the upper $27 \mathrm{~cm}$ of the core used for dating.

Figure 4. Profiles of metal contents $[\mathrm{Me}]$ and metal-aluminum [Me]/[Al] ratios in the sediment core. Dotted lines indicate the dated levels.

Figure 5. Isopycnal maps of Corcubión Sound at $10 \mathrm{~m}$ depth. Favorable upwelling index were measured during the February, May and July data cruises and the previous dates (three days only in the case of May).

Figure 6. Temperature-Salinity diagram from the CTD profile (space: $1 \mathrm{~m}$ of depth distance between marks) of the inner (st.A) and outer (st.C) water stations in February, May and July cruises. TS of the Eastern North Atlantic Central Water mass (ENACW) is highlighted as a gray strip according Sverdrup et al (1946). 

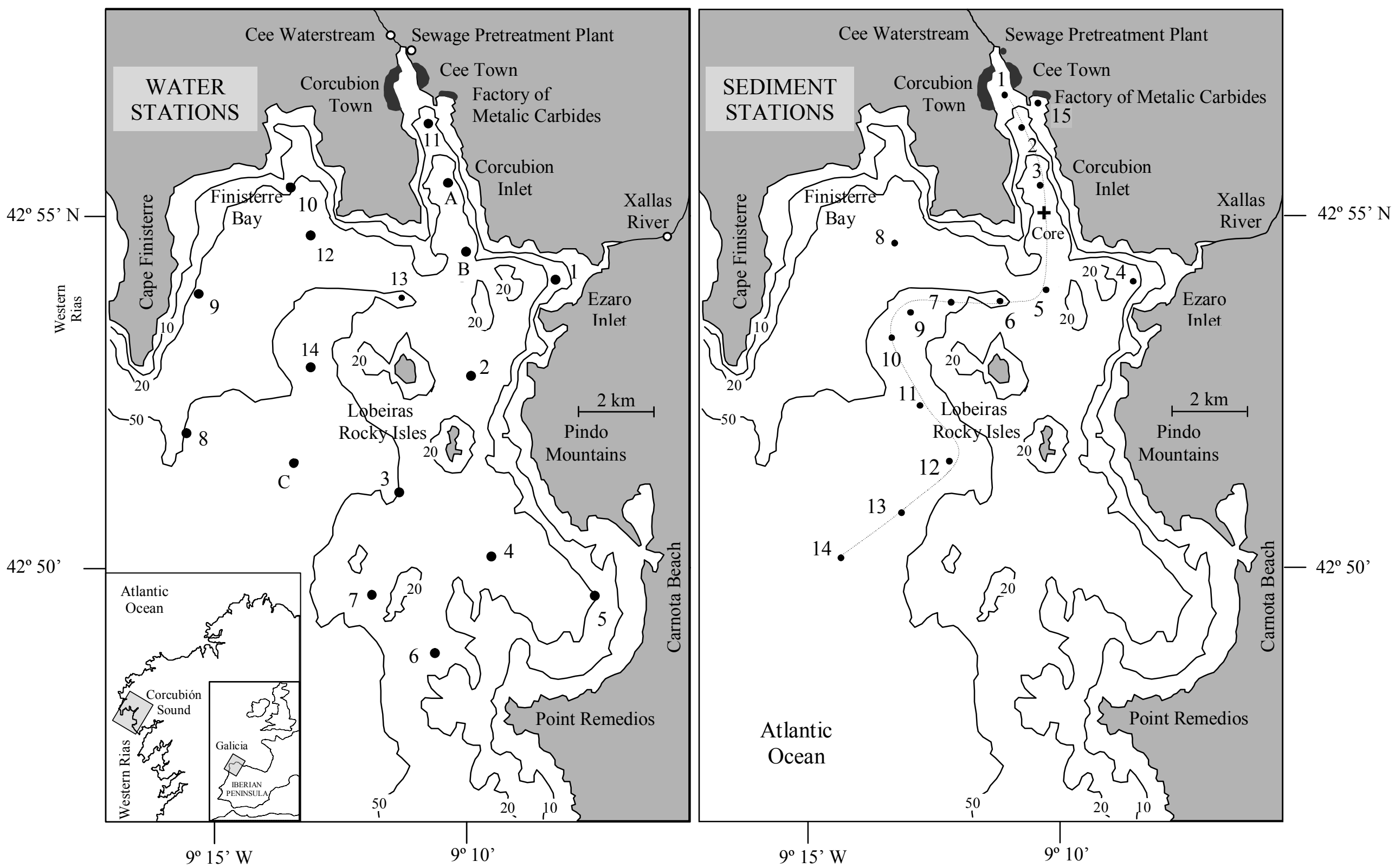

Figure 1 

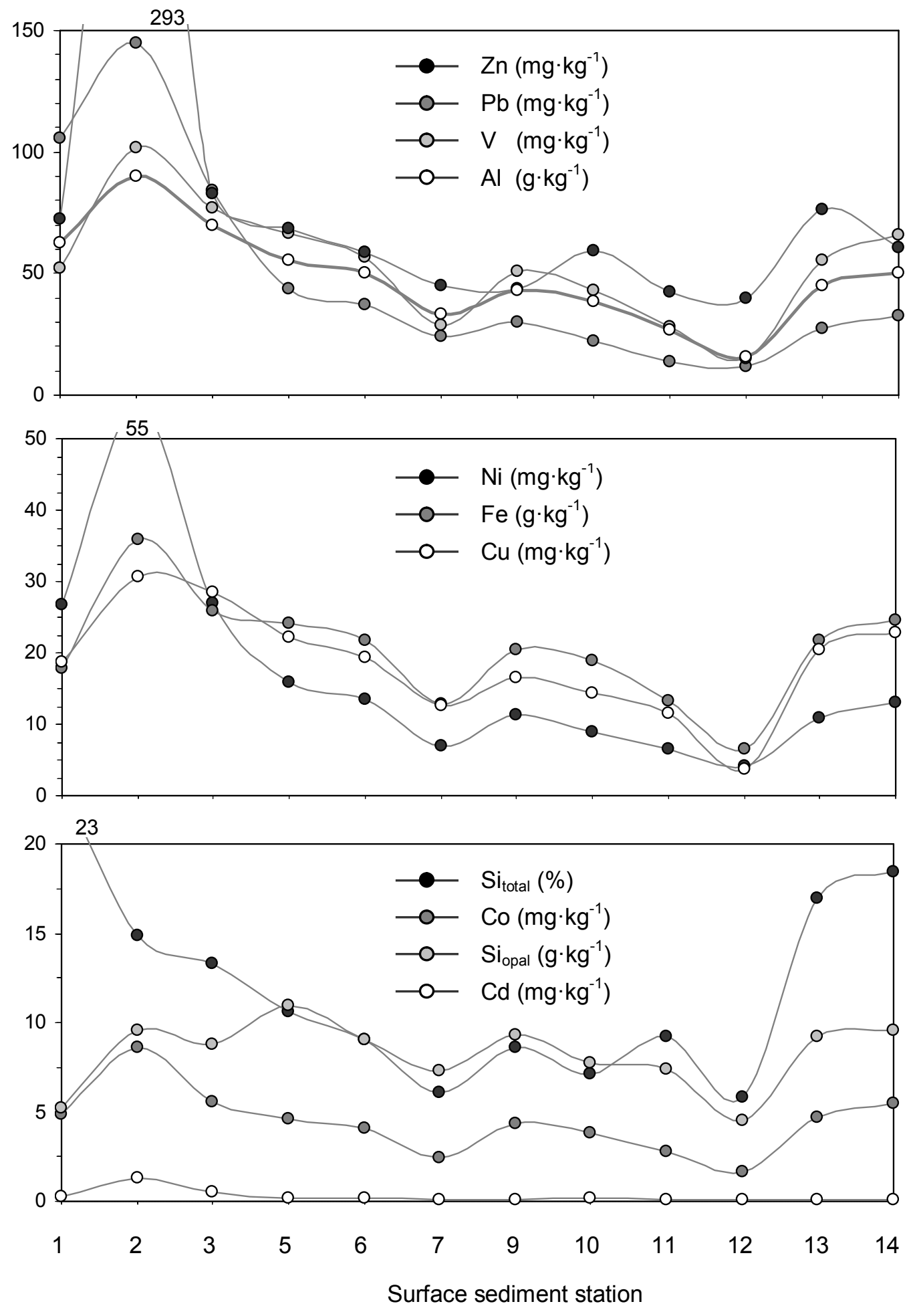

Figure 2 


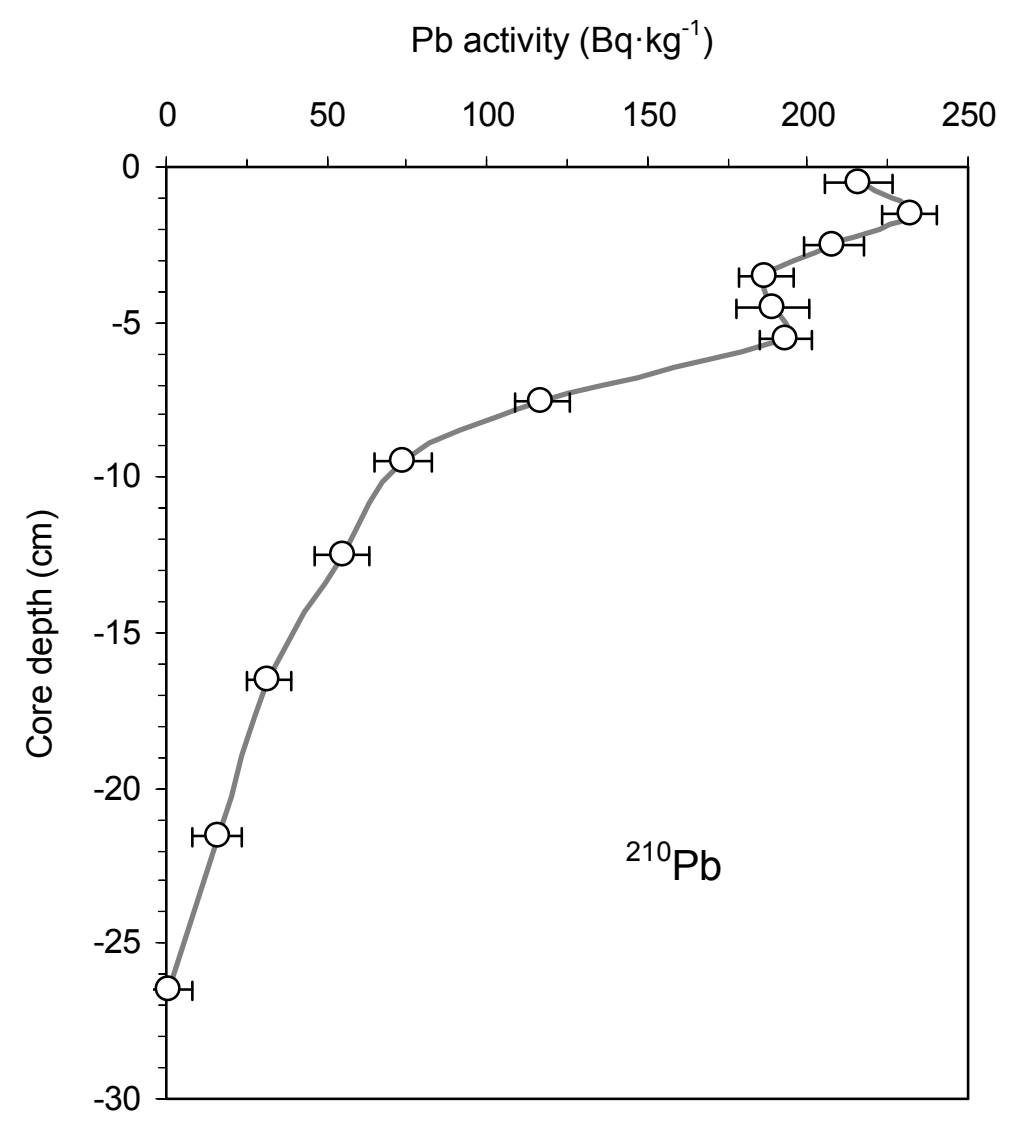

Figure 3 

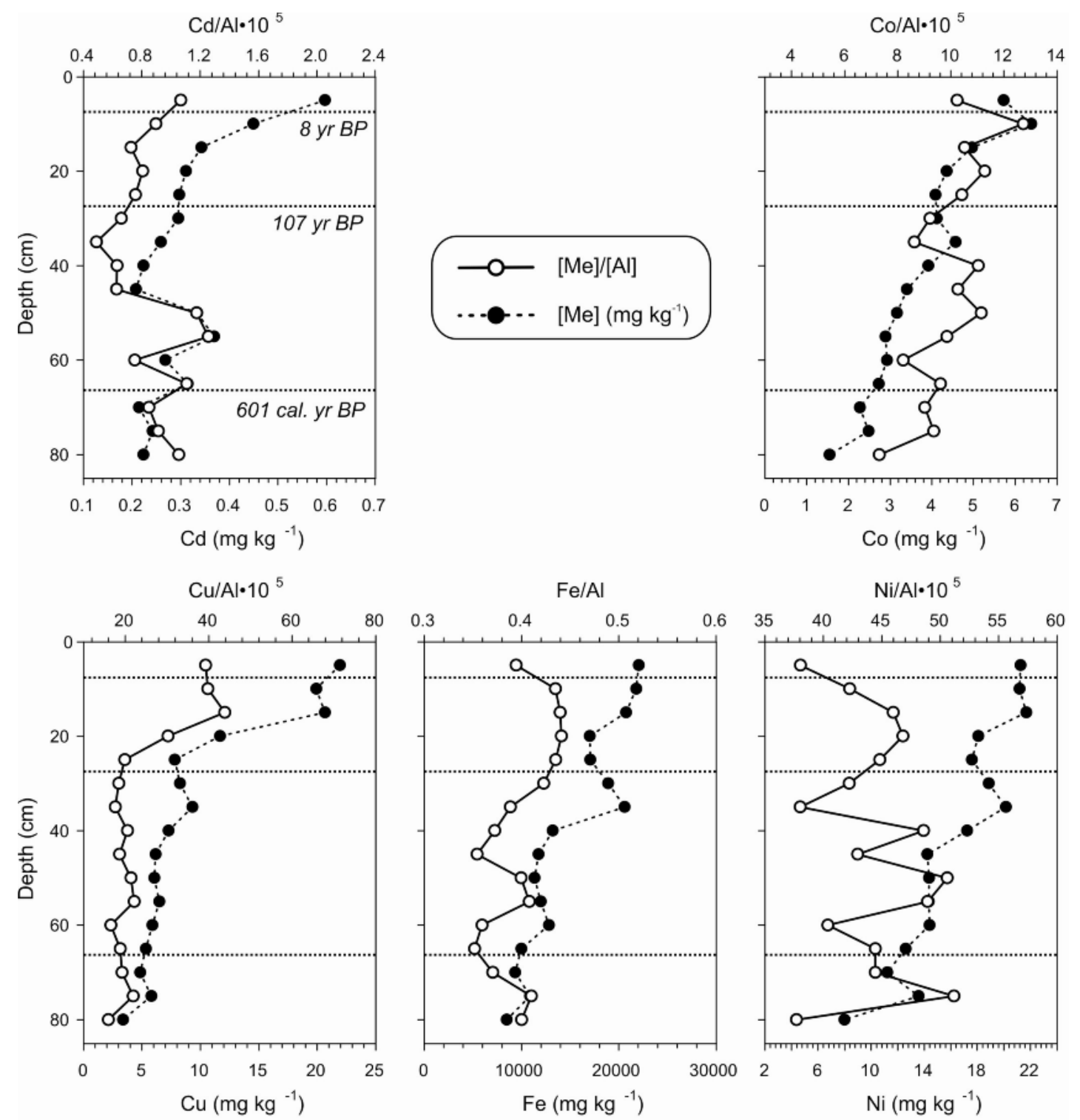

$\mathrm{Pb} / \mathrm{Al} \cdot 10^{5}$

$\mathrm{V} / \mathrm{A} \mid \cdot 10^{5}$
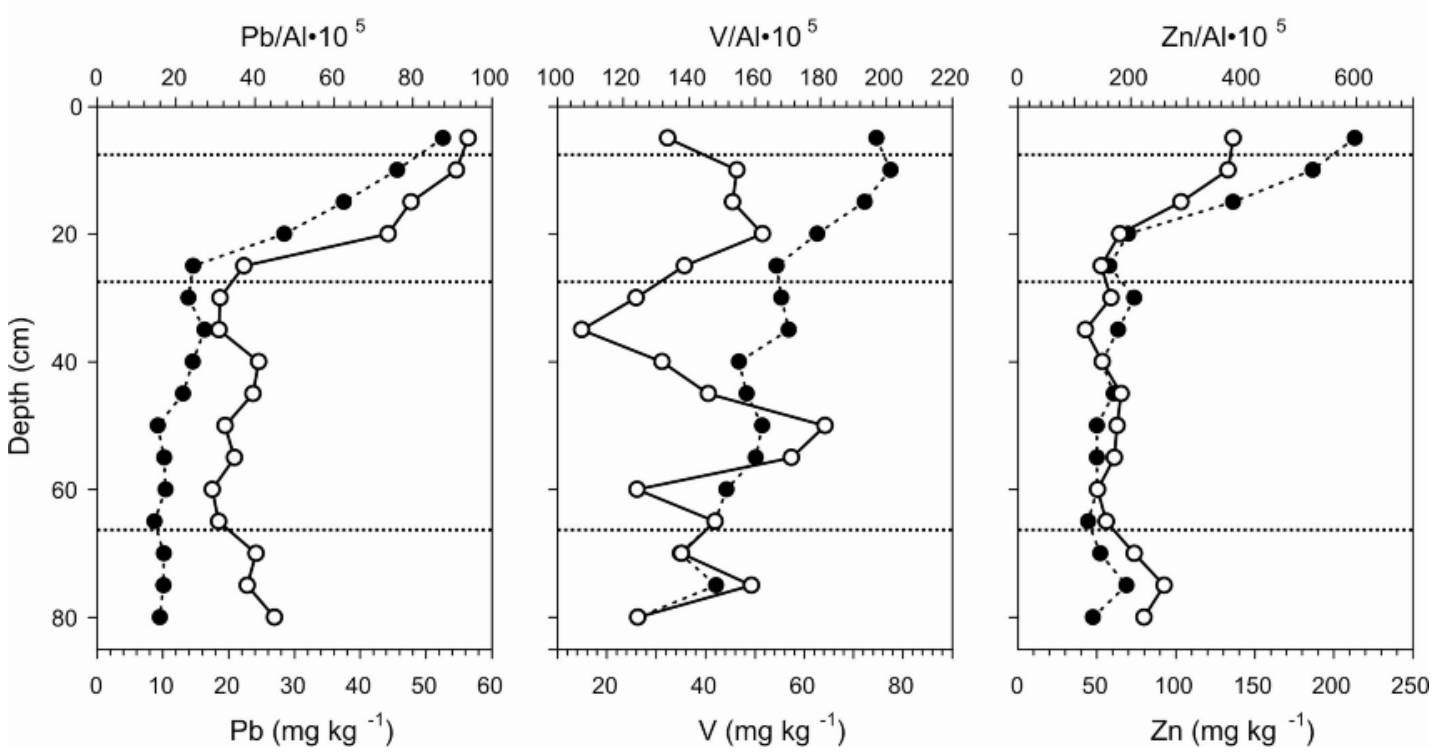

Figure 4 


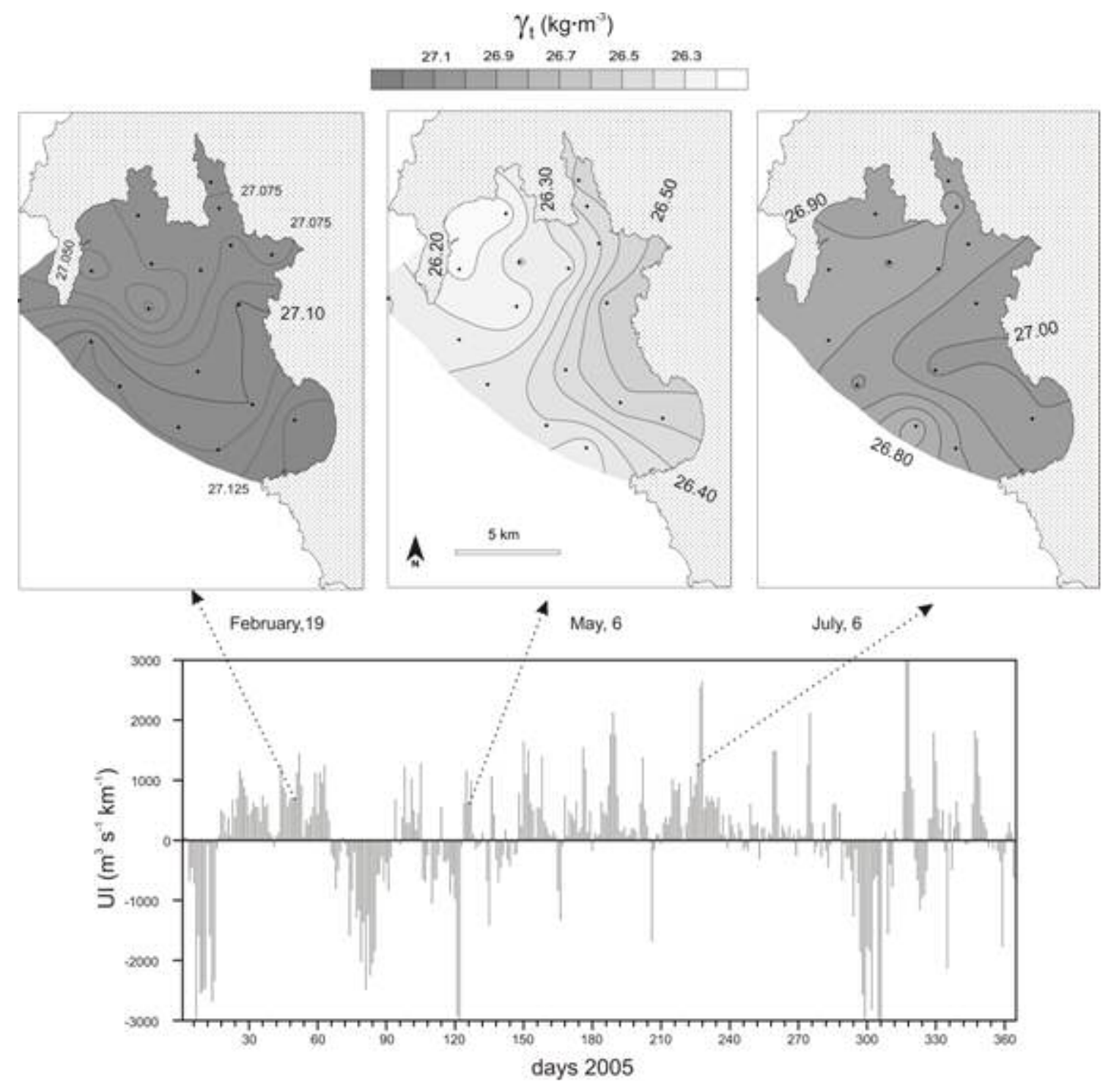

Figure 5 


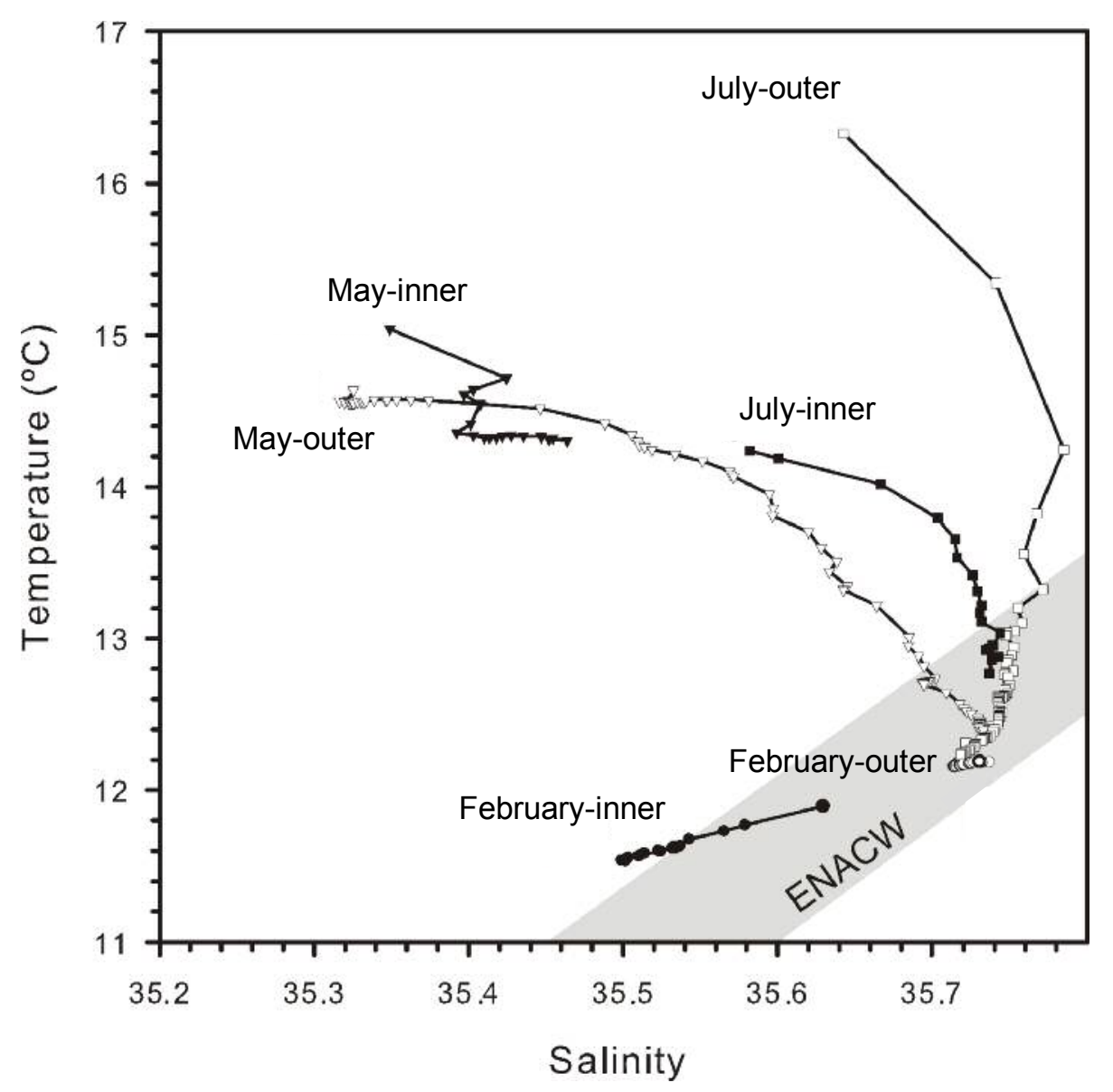

Figure 6 
Table 1.- Results ( $n=6$ ) of Certified Reference Material (NRC, Canada).

\begin{tabular}{|c|c|c|c|c|c|c|c|c|c|c|c|c|}
\hline CRM & & $\mathrm{Al}$ & $\mathrm{Cd}$ & Co & $\mathrm{Cu}$ & $\mathrm{Fe}$ & $\mathrm{Ni}$ & $\mathrm{Pb}$ & $\mathrm{Si}$ & $\mathrm{V}$ & $\mathrm{Zn}$ & unit \\
\hline CASS-4 & analysed & & $0.24 \pm 0.03$ & $0.48 \pm 0.08$ & $9.2 \pm 0.8$ & & $5.4 \pm 0.8$ & $0.068 \pm 0.012$ & & $22.1 \pm 1.3$ & $5.8 \pm 1.0$ & $\mathrm{nM}$ \\
\hline PACS-2 & analysed & & $2.08 \pm 0.07$ & $11.2 \pm 0.3$ & $318 \pm 8$ & & $40.7 \pm 0.2$ & $191 \pm 11$ & & $136 \pm 5$ & $348 \pm 26$ & $\mathrm{mg} \cdot \mathrm{kg}^{-1}$ \\
\hline \multirow{2}{*}{ (sediment) } & analysed & $67.7 \pm 2.9$ & & & & $42.2 \pm 2.9$ & & & $277 \pm 34$ & & & $\mathrm{~g} \cdot \mathrm{kg}^{-1}$ \\
\hline & certified & $66.2 \pm 3.2$ & & & & $40.9 \pm 0.6$ & & & $280^{*}$ & & & \\
\hline
\end{tabular}

*Information value only 
Table 2. Average metal accumulation rates $\left(\mathrm{mg} \cdot \mathrm{m}^{-2} \cdot \mathrm{yr}^{-1}\right.$, except for Fe in $\mathrm{g} \cdot \mathrm{m}^{-2} \cdot \mathrm{yr}^{-1}$ ) calculated from core data (dry bulk density) for each unit.

\begin{tabular}{cccccccccc}
\hline Unit & years & $\mathrm{Cd}$ & $\mathrm{Co}$ & $\mathrm{Cu}$ & $\mathrm{Fe}$ & $\mathrm{Ni}$ & \multicolumn{1}{c}{$\mathrm{Pb}$} & \multicolumn{1}{c}{$\mathrm{V}$} & \multicolumn{1}{c}{$\mathrm{Zn}$} \\
\hline 1 & $2007-2000$ & 10.0 & 99 & 428 & 442 & 412 & 1190 & 1330 & 2660 \\
2 & $1999-1893$ & 1.24 & 16.0 & 39 & 63 & 69 & 75 & 223 & 2240 \\
3 & $1892-1400$ & 0.36 & 3.3 & 7.4 & 15 & 17 & 16 & 54 & 652 \\
\hline
\end{tabular}


Table 3. Ranges of dissolved trace metals in the water column of the inner (Corcubión Inlet) and outer parts of the Corcubión Sound. Units are in $\mathrm{nM}$.

\begin{tabular}{|c|c|c|c|c|c|c|c|c|}
\hline Cruise & Sound part & $\mathrm{Cd}$ & $\mathrm{Co}$ & $\mathrm{Cu}$ & $\mathrm{Ni}$ & $\mathrm{Pb}$ & $\mathrm{V}$ & $\mathrm{Zn}$ \\
\hline \multirow[t]{2}{*}{ February } & Inner & $0.094 \pm 0.039$ & $0.17 \pm 0.04$ & $8.6 \pm 5.9$ & $4.6 \pm 1.2$ & $0.20 \pm 0.09$ & $31.0 \pm 2.9$ & $3.3 \pm 1.5$ \\
\hline & Outer & $0.064 \pm 0.029$ & $0.10 \pm 0.01$ & $2.9 \pm 2.1$ & $4.1 \pm 0.3$ & $0.22 \pm 0.08$ & $31.0 \pm 2.5$ & $2.4 \pm 0.3$ \\
\hline \multirow[t]{2}{*}{ May } & Inner & $0.069 \pm 0.041$ & $0.22 \pm 0.05$ & $2.1 \pm 1.3$ & $4.6 \pm 1.1$ & $0.26 \pm 0.22$ & $30.6 \pm 5.5$ & $4.0 \pm 3.4$ \\
\hline & Outer & $0.086 \pm 0.070$ & $0.13 \pm 0.03$ & $1.1 \pm 0.3$ & $3.9 \pm 0.8$ & $0.29 \pm 0.11$ & $35.2 \pm 3.4$ & $5.6 \pm 0.7$ \\
\hline \multirow[t]{2}{*}{ July } & Inner & $0.076 \pm 0.022$ & $0.26 \pm 0.06$ & $8.0 \pm 6.0$ & $4.1 \pm 0.9$ & $0.38 \pm 0.13$ & $28.9 \pm 5.3$ & $10.7 \pm 2.3$ \\
\hline & Outer & $0.061 \pm 0.030$ & $0.12 \pm 0.02$ & $2.3 \pm 1.2$ & $5.5 \pm 0.7$ & $0.19 \pm 0.12$ & $30.7 \pm 2.8$ & $4.1 \pm 3.3$ \\
\hline Cee stream & Inner & $0.01-0.10$ & $2.3-2.4$ & $16-47$ & $6-12$ & $0.6-0.9$ & $5-8$ & $44-47$ \\
\hline STP* Cee & Inner & $0.04-0.05$ & $20-27$ & $81-97$ & $6-11$ & $6.1-7.3$ & $3-18$ & $150-220$ \\
\hline Xallas River & -- & $0.01-0.07$ & $0.6-2.4$ & $5-14$ & $5-7$ & $0.1-0.2$ & $4-5$ & $5-57$ \\
\hline
\end{tabular}

*Sewage Treatment Plant 
Table 4. Ranges of particulate trace metals in the water column of the inner (Corcubión Inlet) and outer parts of the Corcubión Sound. Units are in $\mathrm{nM}$.

\begin{tabular}{llccccccc}
\hline Cruise & Sound part & $\mathrm{Cd}$ & $\mathrm{Cu}$ & $\mathrm{Fe}$ & $\mathrm{Ni}$ & $\mathrm{Pb}$ & $\mathrm{V}$ \\
\hline February & Inner & $<0.01$ & $0.27 \pm 0.08$ & $112 \pm 34$ & $0.23 \pm 0.16$ & $0.08 \pm 0.04$ & $0.46 \pm 0.15$ & $4.18 \pm 0.90$ \\
& Outer & $<0.01$ & $0.02 \pm 0.02$ & $81 \pm 19$ & $0.07 \pm 0.07$ & $0.22 \pm 0.08$ & $0.11 \pm 0.07$ & $1.30 \pm 0.80$ \\
May & Inner & $<0.01$ & $0.27 \pm 0.20$ & $49 \pm 20$ & $0.09 \pm 0.03$ & $<0.02$ & $<0.07$ & $0.33 \pm 0.11$ \\
& Outer & $<0.01$ & $0.12 \pm 0.05$ & $41 \pm 33$ & $<0.01$ & $<0.02$ & $<0.07$ & $0.53 \pm 0.37$ \\
July & Inner & $<0.01$ & $0.23 \pm 0.16$ & $17 \pm 5$ & $0.15 \pm 0.09$ & $0.05 \pm 0.03$ & $<0.07$ & $0.52 \pm 0.27$ \\
& Outer & $<0.01$ & $0.04 \pm 0.04$ & $<15$ & $0.04 \pm 0.04$ & $0.05 \pm 0.02$ & $0.51 \pm 0.36$ & $0.68 \pm 0.20$ \\
\hline Cee stream & Inner & $3.6-5.8$ & $9-44$ & $975-4050$ & $0.6-4.0$ & $1.0-3.8$ & $0.8-5.1$ & $7-54$ \\
STP* Cee & Inner & $2.2-4.8$ & $12-425$ & $220-3140$ & $1.0-2.7$ & $0.9-17.1$ & $0.9-2.8$ & $16-169$ \\
Xallas River & -- & $8.6-10.5$ & $1-35$ & $1830-16800$ & $2.3-15.0$ & $0.5-8.3$ & $2.6-22.3$ & $5-87$ \\
\hline
\end{tabular}

*Sewage Treatment Plant 
Table 5. Most abundant diatom genus in the water column and in the dry surface sediment in the innermost (St.A and St.1-3, respectively) and outermost (St.C and St.11-14; Fig.1) stations of the Corcubión Sound. Data are stated as means ( $\mathrm{x} \pm$ std) and percentages of abundance (in brackets) for the groups present in the water column and as percentage of abundance for the groups identified in the surface sediment.

\begin{tabular}{llcccc}
\hline & \multicolumn{1}{c}{$2005:$} & February & May & July & Year \\
Sound part & Diatom group & \multicolumn{2}{c}{ Water: } & cells· $\mathrm{mL}^{-1}(\%$ abundance $)$ & Sediment: \% abundance \\
\hline Inner & Chaetoceros & $10 \pm 16(4 \%)$ & $<1(<1 \%)$ & $2 \pm 4(2 \%)$ & $34 \pm 6^{*}$ \\
& Lauderia & $234 \pm 95(92 \%)$ & - & - & - \\
& Paralia & $2 \pm 2(1 \%)$ & - & $1 \pm 2(1 \%)$ & $2 \pm 2$ \\
& Pseudonitzschia & $2 \pm 2(1 \%)$ & $26 \pm 15(90 \%)$ & $34 \pm 18(31 \%)$ & - \\
& Leptocylindrus & $1 \pm 1(<1 \%)$ & - & $61 \pm 78(55 \%)$ & $4 \pm 4^{* *}$ \\
& Thalassionema & $<1(0 \%)$ & - & - & $3 \pm 3$ \\
\hline Outer & Chaetoceros & $5 \pm 9(6 \%)$ & $1 \pm 1(4 \%)$ & $1 \pm 4(<1 \%)$ & $21 \pm 6^{*}$ \\
& Lauderia & $74 \pm 44(87 \%)$ & - & - & - \\
& Paralia & - & - & $1 \pm 2(<1 \%)$ & $38 \pm 4$ \\
& Pseudo-nitzschia & $2 \pm 1(2 \%)$ & $10 \pm 7(79 \%)$ & $82 \pm 117(6 \%)$ & - \\
& Leptocylindrus & - & - & $1225 \pm 3000(93 \%)$ & $6 \pm 5^{* *}$ \\
& Thalassionema & $<1(0 \%)$ & - & - & $15 \pm 11$ \\
\hline
\end{tabular}

*Chaetoceros resting spores in the surface sediment. **Leptocylindrys danicus resting spores in the surface sediment. ( - ) is not present. 
Table 6. Concentrations of chlorophyll $(a+b+c)$ in the photic layer and metals in the phytoplankton of Corcubión Sound. The averaged relationships of metal to silicon in phytoplankton and to Si-opal in surface sediment are also shown.

\begin{tabular}{lccccccccc}
\hline Cruise & $\mathrm{Chl}\left(\mathrm{mg} \cdot \mathrm{m}^{-3}\right)$ & $\mathrm{Cd}\left(\mathrm{mg} \cdot \mathrm{kg}^{-1}\right)$ & $\mathrm{Cu}\left(\mathrm{mg} \cdot \mathrm{kg}^{-1}\right)$ & $\mathrm{Fe}\left(\mathrm{g} \cdot \mathrm{kg}^{-1}\right)$ & $\mathrm{Ni}\left(\mathrm{mg} \cdot \mathrm{kg}^{-1}\right)$ & $\mathrm{Pb}\left(\mathrm{mg}^{\mathrm{kg}} \mathrm{kg}^{-1}\right)$ & $\mathrm{Si}\left(\mathrm{g} \cdot \mathrm{kg}^{-1}\right)$ & $\mathrm{V}\left(\mathrm{mg}^{\mathrm{kg}}{ }^{-1}\right)$ & $\left.\mathrm{Zn}(\mathrm{g} \cdot \mathrm{kg})^{-1}\right)$ \\
\hline February & 9.90 & $0.30 \pm 0.07$ & $14.0 \pm 3.8$ & $4.3 \pm 1.2$ & $11.0 \pm 0.3$ & $24 \pm 8$ & $65 \pm 5$ & $13.6 \pm 4.7$ & $0.59 \pm 0.36$ \\
May & 0.86 & $2.03 \pm 1.45$ & $9.4 \pm 2.1$ & $3.6 \pm 1.5$ & $7.1 \pm 1.5$ & $19 \pm 4$ & $16 \pm 14$ & $6.7 \pm 4.2$ & $0.60 \pm 0.28$ \\
July & 2.74 & $3.23 \pm 0.89$ & $30.0 \pm 12.3$ & $9.6 \pm 1.0$ & $14.6 \pm 5.7$ & $20 \pm 8$ & $21 \pm 3$ & $17.9 \pm 5.0$ & $0.58 \pm 0.23$ \\
\hline Phytoplankton & Metal/Si & $74 \cdot 10^{-6}$ & $0.92 \cdot 10^{-3}$ & 0.28 & $0.52 \cdot 10^{-3}$ & $1.09 \cdot 10^{-3}$ & -- & $0.49 \cdot 10^{-3}$ & $9.2 \cdot 10^{-3}$ \\
Sediment & Metal/Si (opal) & $30 \cdot 10^{-6}$ & $2.0 \cdot 10^{-3}$ & 2.2 & $2.5 \cdot 10^{-3}$ & $5.9 \cdot 10^{-3}$ & -- & $6.5 \cdot 10^{-3}$ & $9.6 \cdot 10^{-3}$ \\
\hline
\end{tabular}

